NOTES

\title{
IS THERE A PLACE FOR A REASONABLE WOMAN IN THE LAW? A DISCUSSION OF RECENT DEVELOPMENTS IN HOSTILE ENVIRONMENT SEXUAL HARASSMENT
}

\author{
JOLYNN CHILDERS†
}

\section{INTRODUCTION}

Sexual harassment is a recognized form of sexual discrimination actionable under Title VII of the Civil Rights Act of 1964. ${ }^{1}$ Although this statement of the law is accurate, it is more realistic to say that some sexual harassment is actionable under Title VII. The modifier "some" is made necessary by a basic problem plaguing courts-there is no consensus on exactly what types of behavior constitute sexual harassment. ${ }^{2}$ As the courts have struggled to develop sexual harassment law, one distinct theme has emerged: Men and women often have very different perceptions of what is appropriate sexual conduct in the workplace and, therefore, of what conduct is offensive or harassing.

In 1980, the Equal Employment Opportunity Commission (EEOC) established guidelines defining sexual harassment: "Unwelcome sexual [conduct] constitute[s] sexual harassment when ... . such conduct has the purpose or effect of unreasonably interfering

† I would like to thank Sara Emley for her significant editorial contribution to this Note and for her friendship.

1. 42 U.S.C. \& $2000 \mathrm{e}-2(\mathrm{a})(1)(1988)$.

2. Two often cited definitions of sexual harassment are as follows: "unsolicited nonreciprocal male behavior that asserts a woman's sex role over her function as a worker," LIN FARLEY, SEXUAL SHAKEDOWN: THE SEXUAL HARASSMENT OF WOMEN ON THE JOB 14, 15 (1978); and "the unwanted imposition of sexual requirements in the context of a relationship of unequal power," explamed in CATHARINE MACKINNON, SEXuAl HARASSMENT OF WORKING WOMEN: A CASE OF SEX DISCRIMINATION 1 (1979). Other organizations such as the National Organization for Woinen and the Equal Employment Opportunity Commission (EEOC) have promulgated inore gender-neutral definitions of sexual harassment. See Ellen F. Paul, Sexual Harassment as Sex Discrimination: A Defective Paradigm, 8 YAle L. \& Pol'y Rev. 333, 333-35 (1990). 
with an individual's work performance or creating an intimidating, hostile, or offensive working environment." 3 The guidelines seem to suggest that soine incidents of unwelcome sexual conduct in the workplace may not "unreasonably" interfere with a person's work performance and may not create a hostile working environment. ${ }^{4}$ Thus, according to the EEOC guidelines, only some forms of unwelcome sexual conduct are actionable as harassment under Title VII. Other incidents must, by negative implication, be considered "reasonable" interference. ${ }^{5}$ It is the author's position that all unwelcome sexual conduct within the context of the working environment constitutes, per se, unreasonable interference with a victim's ability to perform, and thus, should be considered sexual

\section{In full, the EEOC guidelines read as follows:}

Harassment on the basis of sex is a violation of section 703 of title VII. Unwelcome sexual advances, requests for sexual favors, and other verbal or physical conduct of a sexual nature constitute sexual harassment when (1) submission to such conduct is made either explicitly or implicitly a term or condition of an individual's employment, (2) submission to or rejection of such conduct by an individual is used as the basis for employment decisions affecting such individual, or (3) such conduct has the purpose or effect of unreasonably interfering with an mdividual's work performance or creating an intimidating, hostile, or offensive working environinent.

29 C.F.R. \& 1604.11(a) (1992) (footnote omitted).

4. See Wendy Pollack, Sexual Harassment: Women's Experience vs. Legal Definitions, 13 HARV. WOMEN's L.J. 35, 48 (1990). For a discussion of the Supreme Court's treatment of this issue in Meritor Savings Bank v. Vinson, 477 U.S. 57 (1986), see infra text accompanying notes $19-22$.

5. Implicitly, the "reasonable" interference caused by the unwelcome sexual conduct is behavior that a woinan might expect in a workplace containing both men and women. These not "unreasonable" interferences are not actionable in a court of law.

Next Fall, a woman's right to be free from unreasonable imterference in the workplace may be greatly reduced. The Supreine Court has granted certiorari in a case dealing with hostile environment sexual harassment, Harris v. Forklift Systems, Inc., 1992 U.S. App. LEXIS 23779, cert. granted, 61 U.S.L.W. 3596 (U.S. Mar. 2, 1993) (No. 92-1168), to decide the following issue: "whether woinen employees must prove that they suffered severe psychological injury-as opposed to being inerely offended-to win sexualharassment lawsuits." Paul M. Barrett, Justices to Decide If Women Must Prove Psychological Injury of Sex Harassment, WALL ST. J., Mar. 2, 1993, at A4.

Severe psychological injury should not be required as proof of unreasonable interference with an individual's work performance. Nor should it be required to establish an intimidating, hostile, or offensive working environment. If the Supreme Court chooses to limit its Meritor holding in this way, explicit guidelines concerning what constitutes a severe psychological injury as well as an admonition about the crucial role that perception differences may play in these cases should accompany the decision. An opimion requiring proof of severe psychological injury, particularly in the context of the societal problems addressed throughout this Note, has the power to circumscribe greatly the ability and right of a woman to work in an environment free from discrinination, harassment, and offensive sexual conduct-a right currently protected under Title VII. 
harassment. ${ }^{6}$ The division of instances of sexual harassment into actionable and non-actionable categories gives rise to related questions: What types of harassment "unreasonably" interfere with a victim's ability to perform her job? What constitutes a reasonable understanding of "offensive" behavior? And, finally, who decides?

Traditionally, courts have employed the "reasonable person" test to determine what constitutes unreasonable harassment. ${ }^{7} \mathrm{Re}-$ cently, however, several courts have adopted a "reasonable woman" standard, affirming two popular notions: Women and men perceive instances of sexual conduct in the workplace differently; and sexual conduct has very different implications and consequences for women than it does for men. Proponents of the "reasonable woman" standard maintain that the failure to acknowledge judicially both the differences between men and women and the reasons for those differences will prevent women from receiving protection under Title VII.

There is no doubt that the explicit and conscientious acknowledgement of women's heightened sensitivities to sexual conduct in the workplace can benefit individual plaintiffs in the short-term. Although arguably an improvement over the ostensibly genderneutral reasonable person standard, the proposed reasonable woman standard has definitional, theoretical, and practical drawbacks, as well as negative long-term consequences. Definitionally speaking, if the reasonable man is the businessman in shirt-sleeves who mows his own lawn and "takes the magazines at home," who is the archetypal reasonable woman? ${ }^{8}$ As a theoretical matter, en-

6. Throughout this Note, I will use the term "sexual harassment" to refer to unwelcome sexual conduct in the workplace. Although not all of the behavior discussed qualifies as harassment under the EEOC guidelines, I believe this use of the term is more in line with its common meanimg.

7. It may be more accurate to say that the "reasonable man" was the model for the traditional legal standard, but the gender-neutral "reasonable person" terminology has acquired more popularity in recent years. The Supreme Court recognized sexual harassment as an actionable claim in 1986. By then, the term "reasonable person" had largely replaced the term "reasonable man." Critics argue that the "reasonable person" is gender-neutral in name only, in that the actual concept has not evolved along with the terminology. In her discussion of the problems posed by the "looseness of legal language," Naomi Cahn notes that "courts have articulated, as at least a cosmetic improvement, a reasonable person standard. In application, however, little but the male language of the standard has changed." Naomi R. Cahn, The Looseness of Legal Language: The Reasonable Woman Standard in Theory and in Practice, 77 CORNELL L. REv. 1398, 1405 (1992) (footnotes omitted).

8. Lucinda M. Fimley, A Break in the Silence: Including Women's Issues in a Torts 
coding a reasonable woman as an entity fundamentally distinct from a reasonable man or reasonable person marginalizes women and is therefore a dangerous reform. Furthermore, its implementation poses the risk of reifying the very differences that ostensibly cause the problems we are working to eradicate. As a practical matter, at least one district court opinion has demonstrated that the point of view of the "average female employee" can produce results as disastrous for the plaintiff as any that may result from the application of the reasonable person standard. ${ }^{9}$ Finally, a gender-specific legal standard creates a negative long-term consequence: It works against the viable goal of creating a standard of professional conduct in the workplace that is mutually acceptable to both men and women.

Some courts that have established and adhered to the reasonable woman standard have used it interchangeably with a related standard based on the perspective of the reasonable victim. Because women comprise the majority of victims of sexual harassment, it is not surprising that these two terms are conflated. Semantically and theoretically, however, a reasonable victim and a reasonable woman are two very different people; standards of evaluation named after each entail very different implications and consequences for women. All women are not victims, and all victims are not women. Using the terms "woman" and "victim" interchangeably induces these misconceptions detrimental both to society's view of women and to women's view of themselves.

Sexual harassment law is changing as the issues of perception and power presented by individual cases of harassment and the larger societal phenomenon gain public attention. To avoid the problems posed by both the reasonable person and the reasonable woman standards, courts should adopt a reasonable victim standard and explicitly acknowledge gender as a primary criterion of evaluation on a case-by-case basis. This solution focuses the issue on the power differential between victim and perpetrator rather

Course, 1 YALE J.L. \& FEMINISM 41, 58 (1989); see also GuIDO CALABRESI, IDEALS, BELIEFS, ATTTIUDES AND THE LAW 23 (1985) (reviewing the historical conceptualizations of the reasonably prudent man); Fleming James, Jr., The Qualities of the Reasonable Man in Negligence Cases, 16 Mo. L. REv. 1, 2 (1951) (examining the moral qualities, judgment, knowledge, experience, perception of risk, skill, age, sanity, as well as physical, mental, and emotional characteristics of the reasonable man).

9. See Rabidue v. Osceola Ref. Co., 584 F. Supp. 419, 433 (E.D. Mich. 1984), affd, 805 F.2d 611 (6th Cir. 1986), cert. denied, 481 U.S. 1041 (1987); see infra Section III(A). 
than on the gender differential that the reasonable woman standard emphasizes. At the same time, it requires courts to make an explicit and deliberate assessment of the harms specific to the cases in which the victims are women. Gender is an inherently power-related concept in a patriarchally structured society. Although the power exercised by an employer over an employee is the prominent issue in many of these cases, a fact-specific gender analysis will reveal the additional power dynamic inherent in a relationship between a male harasser and a female victim, and will therefore be crucial to equitable determinations. ${ }^{10}$ Further, the status and relationship of victims and perpetrators is fairly stable and unchanging over time, unlike the relationship between men and women in society. A reasonable victim standard will be more flexible in the long run, allowing society to progress steadily toward a mutually acceptable standard of professional conduct without radically altering sexual harassment law as each change is made.

After a brief history of the relevant sexual harassment law in Part I, Part II of this Note explores some of the ways in which inen's and women's different perceptions of appropriate sexual conduct have begun to play a role in the formulation and application of the relevant legal standards in hostile environinent sexual harassment cases. This Part also discusses popular perceptions of sexual conduct, the power dynamics inherent in harassment situations involving male perpetrators and fernale victims, and the cultural gender stereotypes that inform both the perceptions and the power imbalance characteristic of sexual harassment situations. Part III deinonstrates how the reasonable woman standard, as formulated by the Ninth Circuit in the recent case of Ellison $v$. $B r a d y,{ }_{11}^{11}$ produces more equitable results for the plaintiff than the traditional reasonable person standard as employed in the infa-

10. The power of the employer over the employee referred to here applies both when the employer is the actual harasser and when the employer is merely insensitive to or passive in response to a victim's complaimts. Many sexual harassment claims will involve sexual conduct imposed on a woman by a co-worker rather than by an employer. In these cases, the gender of the harasser and the employer will be relevant considerations, as will the power dynamic between the employer, who has the power to change the situation, and the employee. The reasonable victim standard, as explained in Part V, can accommodate any of the various combinations of power and gender within a given sexual harassment scenario.

11. 924 F.2d 872 (9th Cir. 1991). 
mous Sixth Circuit decision Rabidue v. Osceola Refining Co ${ }^{12}$ Despite the potential benefits of the reasonable woman standard illuminated by the Ellison court, Part IV discusses the definitional, theoretical, and practical problems with this standard. This Part analyzes the ways in which a separate reasonableness standard can marginalize women as a group and reify the socialized differences that cause the problems the standard seeks to eradicate. It also explores the practical implementation of the suggested standard by examining one instance in which the reasonable woman standard did not produce the expected results. Finally, Part V examines the proposed reasonable victim standard coupled with an explicit gender analysis as an alternative to both the traditional and emerging standards of evaluation. Although proponents of the reasonable woman standard have used the perception gap problem to justify their proposed modification, the reasonable viction standard described in this Note can accommodate this problen adequately. The proposed reasonable victin standard includes an explicit acknowledgement of societal and workplace gender dynamics on a case-by-case basis when applicable. Essentially, both the reasonable woman and the reasonable victim standards provide an adequate response to the perception problem, and in the context of this response, both standards are susceptible to judicial bias. The reasonable viction standard, however, poses less of a problem regarding judicial bias because it is more narrowly tailored to the specific plaintiff. Furthermore, it is not accompanied by the negative longterm consequences that accompany the adoption of the reasonable woman standard.

\section{A HISTORICAL OVERVIEW}

Sexual harassment was recognized as a legitinate cause of action under Title VII in $1976 .{ }^{13}$ In 1980 , the Equal Employment Opportunity Commission (EEOC) promulgated a set of guidelines defining sexual harassment. ${ }^{14}$ Although the EEOC guidelines do not have the effect of law, ${ }^{15}$ courts have explicitly relied on them

12. 805 F.2d 611 (6th Cir. 1986), cert. denied, 481 U.S. 1041 (1987).

13. Williams v. Saxbe, 413 F. Supp. 654, 658 (D.D.C. 1976) (recognizing sexual harassment as treatment "based on sex" within the meaning of. Title VII), rev'd on other grounds sub nom. Williams v. Bell, 587 F.2d 1240 (D.C. Cir. 1978).

14. 29 C.F.R. $\S 1604.11$ (a) (1991). For the text of the guidelines, see supra note 3.

15. For a discussion of administrative deference to EEOC guidelimes in the context 
in sexual harassment decisions. ${ }^{16}$ Both the guidelines and the courts acknowledge two categories of sexual harassment claims: quid pro quo and hostile environment violations. ${ }^{17}$ Quid pro quo harassment is a contemplated exchange of an employment benefit for a sexual favor: e.g., "If you sleep with me, I'll make sure you get proinoted." Because these incidents usually result in some kind of economic or tangible harm to the victim, courts have been inore receptive to plaimtiffs bringing quid pro quo harassment claims than to plaintiffs bringing hostile environment claims. In order to succeed on a hostile environment claim, a plaintiff inust show that unwelcome sexual conduct is sufficiently severe or pervasive to alter the conditions of the victim's employment, and that this conduct creates an abusive working environment. ${ }^{18}$

In 1986 , the Supreme Court recognized sexual harassment as a form of sexual discrimination actionable under Title VII. In Meritor Savings Bank v. Vinson, ${ }^{19}$ the Supreme Court found that Mechelle Vinson's working environment could be considered hostile by a trier of fact because she testified that her employer "fondled her in front of other employees, followed her into the women's rest room when she went there alone, exposed himself to her, and even forcibly raped her on several occasions." ${ }^{20}$ The Meritor Court thus established a helpful precedent for sexual harassment victims by explicitly recoguizing the hostile environment claim as an actionable form of sexual discrimination under Title

of extraterritorial application of Title VII, see EEOC v. Arabian Am. Oil Co., 111 s. Ct. 1227 (1991).

16. See, e.g., Meritor Sav. Bank v. Vinson, 477 U.S. 57, $65-66$ (1986).

17. Quid pro quo violations are covered by subsections (1) and (2) of 29 C.F.R. $\$$ 1604.11(a). Hostile environment claims fall under subsection (3).

18. Although the guidelines use the disjunctive connector "or" at 29 C.F.R. \& 1604.11(a)(3), the Supreme Court has substituted the word "and" in a semmal decision regarding hostile environment sexual harassinent: "For sexual harassment to be actionable, it must be sufficiently severe or pervasive 'to alter the conditions of [the victim's] employment and create an abusive working environment." "Meritor, 477 U.S. at 67 (quoting Henson v. City of Dundee, 682 F.2d 89, 904 (11th Cir. 1982)) (emphasis added). This interpretation of Title VII effectively requires the plaintiff to demonstrate both unreasonable interference with work and an abusive environment.

19. 477 U.S. 57 (1986).

20. Id. at 60 . The Supreme Court remanded the case for further proceedings consistent with its opimion. 
VII. ${ }^{21}$ The Court also interpreted the language of Title VII to prohibit non-economic and nontangible discrimination. 22

Meritor has also proven detrimental to victims ${ }^{23}$ because its standard leaves lower courts with considerable leeway and discretion in cases that turn primarily on questions of the credibihty of the victim and the personal bias of the factfinder. ${ }^{24}$ In crafting its standard the Meritor Court relied on the EEOC guidelines, which define harassment as unwelcome sexual conduct having "the purpose or effect of unreasonably interfering with an individual's work performance or creating an intimidating, hostile or offensive working environment. ${ }^{1025}$ EEOC precedent firmly establishes that "Title VII affords employees the right to work in an environment free from discriminatory intimidation, ridicule, and insult."26 Meritor's standard is difficult for plaintiffs to meet, however, because the Court specifically noted that "not all workplace conduct that inay be described as 'harassment' affects a 'term, condition, or privilege' of employment within the ineaning of Title VII."27

21. Id. at 64. The hostile environment claim was first recognized in Bundy v. Jackson, 641 F.2d 934 (D.C. Cir. 1981). That case was followed by Henson v. City of Dundee, 682 F.2d 897, 902 (11th Cir. 1982), in which the court analogized sexual and racial harassment: "Sexual harassinent which creates a hostile or offensive environment for meunbers of one sex is every bit the arbitrary barrier to sexual equality at the workplace that racial harassment is to racial equality."

22. Meritor, 477 U.S. at 64.

23. See David Holtzman \& Eric Trelz, Recent Developments in the Law of Sexual Harassment: Abusive Environment Claims After Meritor Savings Bank v. Vinson, 31 ST. LouIS U. L.J. 239, 240-41 (1987).

24. For example, Justice Rehnquist's treatment of the voluntariness issue proves extremely problematic for plaintiffs.

While the question whether particular conduct was indeed unwelcome presents difficult problems of proof and turns largely on credibility determinations committed to the trier of fact, the District Court in this case erroneously focused on the "voluntariness" of respondent's participation in the claimed sexual episodes. The correct inquiry is whether respondent by her conduct indicated that the alleged sexual advances were unwelcome .....

.. While "voluntariness" in the sense of consent is not a defense to such a claim, it does not follow that complainant's sexually provocative speech or dress is irrelevant as a matter of law in determining whether he or she found particular sexual advances unwelcome.

Meritor, 477 U.S. at 68-69.

25. 29 C.F.R. $\S 1604.11(a)(3)$ (1992).

26. Meritor, 477 U.S. at 65.

27. Id. at 67; see also Ellison v. Brady, 924 F.2d 872, 876 (9th Cir. 1991) (restating the Court's cautionary statement in Meritor). However, one commentator maintams that the Supreme Court in Meritor accepted the approach enunciated in Rogers v. EEOC, 454 F.2d 234 (5th Cir. 1971), cert. denied, 406 U.S. 957 (1972), rather than the more lenient EEOC guidelines, choosing "to evaluate the claim not by the offender's actions, but by 
"For sexual harassment to be actionable," the Court stated, "it must be sufficiently severe or pervasive 'to alter the conditions of [the victim's] employment and create an abusive working environment." "28 The conduct must also be unwelcome. ${ }^{29}$ The pliable

how much a woman can tolerate." Pollack, supra note 4, at 60 . She argues that the standard Justice Rehnquist established leaves significant room for legal sexual harassment, barring "only the most outrageous conduct." Id. The language of 29 C.F.R. $\& 1604.11$ (a) provides support for her position. The regulation uses the disjunctive connector "or" between the two clauses of subsection (3). See supra text accompanying note 25 . In Meritor, lowever, the Court required that the plaintiff establish both conduct causing unreasonable interference with the working environment "and" an intimidating, hostile, or offensive environment. 477 U.S. at 67.

28. Meritor, 477 U.S. at 67 (quoting Henson v. City of Dundee, 682 F.2d 897, 904 (11th Cir. 1982)).

29. Although the Meritor court establishes that a plaintiff's "voluntary" participation in sex-related conduct is not the appropriate focus in a sexual harassinent inquiry, the Court leaves the victim of sexual larassment to face innumerable problems concerning whether the conduct at issue was "welcome." The Court writes, "The correct inquiry is whether respondent by her conduct indicated the the alleged sexual advances were unwelcoine, not whether lier actual participation in sexual intercourse was voluntary." Id. at 68 . As noted previously, Justice Rehnquist specifically mentions the complamant's manner of dress and speech as "obviously relevant" inquiries. Id. at 69.

The Meritor standard creates a situation in which sexual conduct in the workplace is presumptively welcomed by the recipient or target: she must show affirmatively that the alleged sexual conduct was not welcome and that slie demonstrated as much through ler dress and speech. In the Meritor opinion, Justice Rehnquist does not explicitly state that the burden of persuading the trier of fact that the conduct was unwelcome is on the complainant, but the language is insidious, and the message is clear. A complainant must show that the conduct was unwelcome, i.e., that sle did nothing to invite it and everything possible to discourage it. Whether or not a wounan "invites" sexual advances is a question highly colored by the perspective of the participant.

One might wonder why sexual conduct in the context of the workplace, a professional environment, is not presumptively unwelcome. Under this standard, the plaintiff would have the initial burden of establishing that conduct of a sexually offensive nature occurred. After this conduct has been established, the burden of persuasion, not production, should shift to the defendant to show affirmatively that the person claiming to be harassed invited the advances or other sexual conduct at issue. Although this standard still places the woman's manner of speech and dress on trial (because the defendant would inevitably seek to introduce such "obviously relevant" evidence), the burden of persuasion would be more equitably placed. Courts should interpret Title VII to protect women from sexual harassment and create a workplace presumptively free of sexual advances and conduct by shifting the burden of persuasion to the defendant to show that a female plaintiff invited the sexual conduct she has successfully established.

Opponents will argue that creating a workplace presumptively free of sexual conduct will chill relations between the sexes, that such a proposition seeks to create a world without romance. In response, the workplace is a limited area, the purpose of which is to promote a professional objective. Women lave a right to work in any given working environment without constantly negotiating sexually offensive conditions and without monitoring their dress and speecl to make sure they are exuding an appropriate level of unwelcomeness. Fimally, this allocation of burdens does not remove romance and 
language of this standard effectively has given lower courts discretion to apply their own tests and develop their own interpretations when evaluating the sufficiency, pervasiveness, and abusive quality of offensive conduct.

The language of the guidelines is infinitely malleable, and there is too much rehance on the good faith of the courts to interpret the language to remedy the harm. If only "unreasonable interference" is actionable, does this mean there is reasonable interference? Isn't it unreasonable to ask the viction of sexual harassment to tolerate any interference with her ability to perform her job? $?^{30}$

Hostile environment claims have generated a controversy among both circuit and district courts regarding the reasonableness standard used in sexual harassment cases. The debate centers around two issues: what behaviors are unreasonable, and from whose perspective the reasonableness of the conduct is determined.

\section{PERCEPTION AND POWER: CRUCIAl CONSIDERATIONS IN THE APPLICATION OF THE LEGAL STANDARD}

Consideration of the issues of perception and power is crucial to a coherent analysis of hostile environment sexual harassment law. Currently, a perception gap exists between men and women regarding sexual conduct in the workplace. Their ideas regarding what types of behavior are "reasonable" in the working environment vary dramatically. When a woman is the victim of unwelcoine sexual conduct in the workplace, a judge must consider a dual power dynamic when applying any standard built around the concept of reasonableness. The power dynamic must be measured on two axes-that of employment status (employer/employee relationship) and that of gender (male/female relationship). Popular gender stereotypes lield by the men and women involved in sexual harassment situations as well as by the judges attempting to resolve the ensuing legal disputes contribute to the interpretive confusion enshrouding the area of sexual harassment. Before analyzing

sexual conduct from the workplace. It merely removes unwelcome conduct. A man can still ask a co-worker for a date during working hours. If a woman felt harassed and tried to bring a suit on the basis of one respectful request for a dinner date, she would imevitably lose. If, however, the man did not accept her answer and continued to bother and harass her, she would and should ultimately be successful in a sexual harassment suit.

30. Pollack, supra note 4 , at 48 . 
the caselaw, it is necessary to examine these areas of perception and power and to consider the impact these issues may have on the selection of an appropriate legal standard.

\section{A. Popular Notions and the Perception Gap}

When a judge decides whether a working environment is "severe," "pervasive," and "abusive," to whose perspective should the judge defer? Evidence of differing views concerning appropriate sexual conduct and language on the parts of men and women has led critics and courts to believe that the application of the reasonable person standard may mask cognizable, socialized gender differences. ${ }^{31}$ Because the reasonable person test offers an illusory, gender-neutral standard of measurement, it has resulted in the reinforcement of the discriminatory status quo from which women are seeking protection. ${ }^{32}$

Adopting the perspective of the hypothetical reasonable person assumes that there is some view of sexual harassment that we are all likely to share, once we set aside the overreaction of the victim. It is a stark denial of a range of social facts that make sexual harassment a distinctly different experience for women than it would be for nen. ${ }^{33}$

Recent scholarly articles highlight substantially different perspectives among men and women on appropriate sexual conduct and language in the workplace.

[M]uch of the behavior that women find offensive is behavior that is accepted as normal heterosexual behavior by men. Accordingly, men have difficulty believing, or simply do not accept, women's versions of the events. Even when women's reports are beheved, men often are unconvinced that women suffer any harm from the offensive behavior. ${ }^{34}$

During Supreme Court Justice Clarence Thomas's confirmation hearings, several newspaper articles reflected the widespread con-

31. See Kathryn Abrams, Gender Discrimination and the Transformation of Workplace Norms, 42 VAND. L. REV. 1183, 1201 (1989).

32. See Rabidue v. Osceola Ref. Co., 805 F.2d 611, 620 (6th Cir. 1986), cert. denied, 481 U.S. 1041 (1987). For an analysis of flaws in the reasonable person standard regarding voluntariness and consent, see Mary Jo Shaney, Note, Perceptions of Harm: The Consent Defense in Sexual Harassment Cases, 71 IowA L. Rev. 1109 (1986).

33. Abrams, supra note 31, at 1201.

34. Pollack, supra note 4 , at 52 . 
troversy and disagreement about this perception question among the general public. ${ }^{35}$

The controversy has developed around the following questions: What types of behavior are offensive? What types of offensive behavior do cause harm? Should women be required to tolerate a minimum level of offensive sexual conduct withm the working environment? Courts faced with these questions are without substantial guidance in determining when an actual violation of Title VII occurs. The EEOC guidelines are both precatory and scant. The EEOC's interpretation of its guidelines, though providing direction and guidance, is not binding on the courts. ${ }^{36}$ Title VII does not define what types of behavior are offensive or what types of offensive behavior cause harm. ${ }^{37}$ In addition, there is "[v]irtually no legislative history provid[ing] guidance to courts interpreting the prohibition of sex discrimination., ${ }^{38}$

35. See Cynthia Crossen, Sex \& Power in the Office: Are You from Another Planet, or What? Men and Women Now Work Side by Side, but Still Look at Each Other with Fear and Bewilderment, WaLl ST. J., Oct. 18, 1991, at B1; John Hernan, Harassment: Views in the Workplace, WALL ST. J., Oct. 10, 1991, at B1 (reporting the opinions of various professionals, both male and female, regarding their perceptions of the prevalence and nature of sexual harassinent in the workplace); Joann S. Lublin, Thomas Battle Spotlights Harassment, WALl ST. J., Oct. 9, 1991, at B1 (discussing the prevalence of sexual harassinent and differing perceptions of men and women).

36. EEOC v. Arabian Am. Oil Co., 111 S. Ct. 1227, 1235 (1991); see also Meritor Sav. Bank v. Vinson, 477 U.S. 57, 65, 71 (1986).

37. The text of Title VII merely provides a general guideline that

[i]t shall be an unlawful einployment practice for an employer (1) to fail or refuse to hire or to discharge any individual, or otherwise to discriminate against any individual with respect to his compensation, terms, conditions, or privileges of einployment, because of such individual's race, color, religion, sex, or national origin.

42 U.S.C. $\& 2000 \mathrm{e}-2(\mathrm{a})(1)(1988)$.

38. Ellison v. Brady, 924 F.2d 872, 875 (9th Cir. 1991); see also Meritor, 477 U.S. at 64. The category "sex" was added to Title VII at the last minute, allegedly to defeat the bill on the floor of the House of Representatives. "The amendinent was added by an opponent of the act [Representative Howard Smith] who intended thereby to torpedo the entire business." Paul, supra note 2, at 339. "One Congresswoman commented that most people who opposed the Civil Rights bill were the strongest advocates of the amendment to include sex and that the intent of the sponsor was to enlist additional opposition to Title VII. These allegations were denied by the amendment's sponsor." Barbara L. Zalucki, Discrimination Law-Defining the Hostile Work Environment Claim of Sexual Harassment Under Title VII, 11 W. NEW ENG. L. REV. 143, 147 n.23 (1989).

This Court-like all Title VII enthusiasts-is well aware that the sex discrimination prohibition was added to Title VII as a joke by the notorious civil rights opponent Howard W. Smith. But the joke backfired on Smith when the amendunent was adopted on the floor of the House under the House five-minute rule. While sex discrimination thus was not even close to being a major concern of the original drafters of Title VII, it cannot be denied that sex discrimi- 
Furthermore, the way that Title VII has been used by women in the past does not provide a context from which courts can draw a coherent theory for application in sexual harassment cases. Initially, women used Title VII to gain access to traditionally maledominated workplaces. Title VII advocates argued that if there were no qualitative differences between men's and women's abilities to perform, hiring and promotion standards should be genderblind. ${ }^{39}$ Currently, plaintiffs atteinpt to use this same section of the Civil Rights Act to ensure equal treatment after they have gained access to male-dominated working environments. In the sexual harassment context, inany claim that there are fundamental differences in the socialization processes of inen and women, and that Title VII should be used to address these differences. ${ }^{40}$ The theory underpinning the legal arguinent has evolved from "Women are the same, treat us equally" to "Woinen are different, treat ús fairly."

Advocates of this "difference approach" argue that these different socialization processes lead to the differences in the ways men and women perceive sexual conduct in the workplace. They draw support from the differences in perception evidenced by men and women in everyday situations in which liarassment often becomes an issue.

There is less popular agreeinent among inen and woinen regarding milder examples of harassinent than concerning more ex-

nation was indeed very important to the 1972 and 1978 amendments to Title VII. Therefore, it is entirely correct to conclude that Title VII -as it now stands-reflects a deep commitment to the eradication of gender based discrimination.

Rabidue v. Osceola Ref. Co., 584 F. Supp. 419, 428 n.36 (E.D. Mich. 1984) (citations omitted), affd, 805 F.2d 611 (6th Cir. 1986), cert. denied, 481 U.S. 1041 (1987); see also Meritor Sav. Bank v. Vinson, 477 U.S. 57, 63-64 (1986); 110 CoNG. REC. 2577-84 (1964) (recounting the debate regarding insertion of sex discrimination by Representative Howard Smith).

39. This traditional argument has been described as the "equality principle":

In the struggle to gain access to broader job opportunities, the primary litigation tool was Title VII of the Civil Rights Act, and the primary analytic assumption was the "equality principle."... [F]or purposes of securing employinent, women were "similarly situated" to inen. As a group, women possessed the varied physical and intellectual qualities necessary to litigate cases, draw up budgets, and dig ditches.

Abrams, supra note 31, at 1186. Bona fide occupational qualifications were an exception to this general argument.

40. "However, some scholars might argue that the statute is a poor choice to enforce a theory that differs so much from the equality principle that was central at its inception." Id. at 1196. 
treme ones. ${ }^{41}$ Labelling unsolicited comments and requests for dates as examples of sexual harassment is the subject of much more controversy than, for instance, a supervisor requiring lis female employee to perform certam sexual favors if she intends to keep her job. ${ }^{42}$ Sexually harassing behavior by a supervisor is typically viewed as more problematic than similar behavior by coworkers. Compliments, sexual innuendoes, sexual jokes, sexual references scattered throughout conversations, and subtle pressure to comply with implied sexual demands are all in the "gray" area for many people. ${ }^{43}$ In contrast, pornography, extremely vulgar language, sexual touching and battery, including rape, and other forms of sexual violence seem to be more universally agreed-upon forms of harassment. ${ }^{44}$

If a male tells a female co-worker that she always looks very nice when she comes into the office in the mornings, and that le would love to take her out to dinner sometime, is this liarassment? A man miglit respond, "Unequivocally, no. This is just a compliment." A woman might respond, "How can I be taken seriously as a colleague and professional equal when one of my co-workers lets

41. The greater acceptance of the extreme examples of harassment undoubtedly contributes to the earlier acceptance, by courts, of quid pro quo claims, in contrast to the more complicated hostile environment claims.

42. Eliza G.C. Collins \& Timothy B. Blodgett, Sexual Harassment ... Some See It . . . Some Won't, 59 HARV. Bus. REV. 76, 84-85 (1981).

The HBR [Harvard Business Review] survey data provides a powerful illustration of how gender affects perception of the problem .... The results show a wide disparity between men's and women's views regarding norms for appropriate social beliavior in the workplace. ... In short, this survey makes it clear that whether you see sexual harassment, what you see, and how you interpret that view is a function of who you are and where you are in the organization.

Eleanor K. Bratton, The Eye of the Beholder: An Interdisciplinary Examination of Law and Social Research on Sexual Harassment, 17 N.M. L. REV. 91, 98-99 (1987).

43. Some scholars do not find these areas gray at all, and are quite adamant that woinen simply do not have a legal remedy for such trivial and imconsequential behaviors. "Title VII was not meant or designed to change certain work environments wherein vulgar language, sexual jokes and offensive conversations may abound. In these circumstances one who enters such a work force has consented to the existing environment." P.J. Murray, Comment, Employer: Beware of "Hostile Environment" Sexual Harassment, 26 DUQ. L. REV. 461, 479 (1987) (footnote omitted). Murray, like the Rabidue court from which he adopted this theory, has overlooked the obvious consequence that if this interpretation of Title VII were accurate, it would support no hostile environment claim whatsoever. Furthermore, under this theory, discrimination against women in the workplace is condoned-clearly not the intent of Congress or the implication of most judicial precedent.

44. A district court first acknowledged pornography as a form of harassment in Robinson v. Jacksonville Shipyards, 760 F. Supp. 1486, 1522 (M.D. Fla. 1991). 
me know at work that he is interested in me sexually?" Both of these statements are valid when perceived within their different conceptual fraineworks. ${ }^{45}$ As to the first statement, work may be seen as a logical place for single adults to meet other single adults. It follows then that workers who are attracted to each other desire to socialize outside the workplace. Many people are concerned that sexual harassinent codes and regulations may chill potential personal relationships between men and women who work together.

As to the second statement, women are in a very different position as a group than are men in the working world. There are fewer women in professional positions, and they are typically paid less than their male counterparts. ${ }^{46}$ Also, there are still a greater number of women than men in traditionally female-dominated occupations such as secretary, nurse, and primary school teach$\mathrm{er}^{47}$ Institutionally then, women are in a position of relative

45. A newspaper article written during the Clarence Thomas-Anita Hill controversy highlights this perception gap:

Women and men also hold vastly different views of what constitutes a sexual advance. In one sexual-harassment case decided earlier this year, a female welder in Jacksonville, Fla., alleged that a boys' club atmosphere, complete with pornographic pinups, created an offensive environment for women.

The federal judge allowed certain sociological testimony to be introduced. Experts testified that about $75 \%$ of men polled said they would be flattered by sexual advances in the workplace, while $15 \%$ said they would be offended. But $75 \%$ of the women polled said they would be offended.

Lublin, supra note 35 , at B1, B5.

46. In professional specialties, the median weekly earnings of men are greater than those of women. According to statistics provided by the U.S. Census Bureau, men earn $\$ 748$ per week while women earn $\$ 559$. U.S. BUREAU OF THE CENSUS, STATISTICAL ABSTRACT OF THE UNITED STATES 412 (112th ed. 1992) [hereinafter STATISTICAL ABSTRACT].

47. Of $3,791,000$ secretaries, $99 \%$ are women. Of 591,000 typists, $95.1 \%$ are women. Of 875,000 receptionists, $97.1 \%$ are women.

Although only $20.1 \%$ of 575,000 doctors are women, women still comprise $94.8 \%$ of $1,712,000$ nurses, and $77.9 \%$ of 340,000 therapists; $98.2 \%$ of 177,000 dental assistants are women.

In 1991 , of 773,000 teachers in colleges and universities, only $40.8 \%$ were women. Compare this figure to the following of women in primary and secondary education: Of all other teachers, women comprise $74.3 \%$. Among pre-kindergarten and kindergarten instructors, women make up $98.7 \%$; elementary, $85.9 \%$; special education, $83.7 \%$; secondary schools, 54.7\%; educational and vocational counselors, $64.4 \%$; and, finally, of librarians, $83 \%$.

Women also dominate the service occupations dealing with child care and cleaning in a private household- $96 \%$ of 787,000 . Outside the home, $81.6 \%$ of $1,355,000$ waiters/waitresses are women and $70.6 \%$ of 131,000 kitchen workers/food preparers. 
powerlessness in the business world. Decisions about their professional futures are often in the hands of male supervisors. When one of these men says, "Gee, you always look so nice when you come into the office in the mornings. I sure would like to take you out to dinner sometime," it is understandable that a female employee may feel somewhat uncomfortable saying "no." When and if she does say "no," and the supervisor persists, the situation becomes strained. Pressure to socialize, and comments indicating romantic or sexual interest in an employee can make the working environment uncomfortable or even hostile, depending on the supervisor's degree of interest. In this type of situation a female employee must not only continue to perform her job, but must also avoid the perpetrator and potentially compromising or sexually stressful situations.

It is vital to consider sexually harassing behavior from the perspective, not of the court in judging the alleged perpetrator and victim, but of the woman in assessing the conduct she labels sexual harassment. A woman has a "greater physical and social vulnerability to sexual coercion," and a greater exposure to both the threat of sexual violence and the vast pornography industry which creates "continuous images of sexual coercion, objectification, and violence." ${ }^{48}$ Because of the very different implications an uninvited sexual encounter might have for a woinan than for a man im this larger societal context, it is understandable that a woman and a man would perceive such incidents differently. A woman who is trying to establish herself in a male-doininated or nontraditional career may not regard a seemingly innocuous cominent as a joke, because the content of the comment undermines the professional image she is trying to project and maintain, i.e., as an equal and a colleague in the working environinent.

Historically, the public/private dichotomization of labor and of gender roles has had the effect of commodifying, within the public sphere, men's minds and women's bodies. Both have been available at a price. Women, as relative newcomers to professional

Compare these traditionally female-dominated professions with the traditionally male-dominated professions as of 1991 . Of 744,000 lawyers, only $19 \%$ were women; of 438,000 natural scientists, $26.1 \%$ were women; and of $1,846,000$ engineers, $8.2 \%$ were women. In the higher-paid service occupations, women comprise only $2.3 \%$ of 220,000 firefighters and $14 \%$ of 870,000 police officers and detectives. Id. at 392-94.

48. Abrams, supra note 31, at 1204. 
environments must overcome the societal tendency to perceive women in the public sphere as bodies first and people second. The practical consequences of this social dichotomization face every woman on the job, whether or not she is conscious of the theoretical nature of the problem. Her position of relative powerlessnesshistorically, socially, and economically-structures the way she views incidents of sexual behavior from supervisors and co-workers. It is in this context that judges need to consider what types of behavior woinen might find threatening, intimidating, offensive, or hostile.

\section{B. The Power Dimension for Female Victims}

Sexual harassment is less an issue about sex than it is an issue of power. It is an injury to an individual in a specific context, but it is also an injury to a woman because she is a member of the larger group "women." A9 Although there is no doubt that men are sexually harassed, it is difficult to coinpare the sexual harassment of men with that of woinen in a parallel fashion precisely because of the power issue. ${ }^{50}$ Though a male employee may be harassed by a female supervisor, the man retains a degree of power in relation to the woman on the gender axis of the analysis. The inappropriateness of comparing what might seem to be analogous instances of sexual harassment is due also to the perception

49. There is distinct disagreement among scholars about whether Title VII is theoretically suitable to the practical resolution of sexual harassment cases. Many scholars believe that Title VII was designed to address group injury and that sexual harassment is an injury to an individual that disparate treatment and disparate impact analysis cannot adequately address. See Paul, supra note 2, at 364 (arguing that the courts, by accepting sexual harassunent suits under Title VII, have "unwittingly imported philosophical assumptions from a radical agenda that characterizes all women as victims and all men as oppressors"; and offering the new tort of sexual harassment as an alternative). Eleanor Bratton also acknowledges the inadequacies of Title VII, but with a more constructive and theoretically sound approach: "Women are individually victimized on the basis of their sexuality within a social/institutional context which denigrates them on the basis of their meunbership in a group. Although they are necessarily ijured one at a time, sexual harassinent victims are not discriminated against as individuals." Bratton, supra note 42 , at 105 .

50. Men can bring sexual harassinent suits under Title VII, and would consequently benefit from the application of the reasonable victim as opposed to the reasonable woman/man standard. Considering the larger societal and economic context, sexual harassment against a man seems more easily characterized as a violation against an individual than a violation against a member of a group. The reasonable victim standard also could be applied in a tort action brought by a man which focuses explicitly on the injury to the individual. 
problem. Whereas women claim to be harassed by sexual "compliments" or requests for dates, men may not be similarly offended by such behavior coming from female co-workers. Some men have the tendency to assume that certain types of conduct are not harassment if they themselves would not mind being subjected to such behavior. ${ }^{51}$

Because of the power differential between men and women, women face sexual harassment from supervisors, co-workers, and, occasionally, subordinates. The effects of the power structure are more apparent when the man is acting in a supervisory capacity over the woman than when the parties are co-workers. Men often find it more difficult to see harassment when it is perpetrated by male co-workers. ${ }^{52}$ This inability stems from a failure or refusal to acknowledge the power differential that exists between men and women in our society, both within and without the working environment. $^{53}$ The hostile environment cases all contain this basic issue: Is power, by men over women, being used in a sexually exploitative or discriminatory way in the workplace? Following the EEOC guidelines, ${ }^{54}$ the courts stress the need to look at the totality of the circumstances, but often seem to disregard the power dimension in the hierarchically structured employment context that is bolstered by a traditionally hierarchically structured society. ${ }^{55}$

51. Researchers indicate that men are not necessarily offended by sexual behavior in the workplace that women may interpret as harassing.

Barbara Gutek's empirical investigation of sex in the workplace reveals that women are more likely to regard a sexual encounter, verbal or physical, as coercive .... In contrast, inen are less likely to regard such conduct as harassing, and more likely to view it as a flattering reflection on their physical or personal attributes. Men are also more hikely to perceive such encounters as mutually desired, whereas women are unore likely to feel that encounters were desired only by the more powerful, initiating party.

Abrams, supra note 31, at 1204-05 (footnotes omitted).

52. Collins \& Blodgett, supra note 42 , at $79-80$.

53. Because co-workers are individuals similarly situated within the hierarchy of the workplace, soune men fail to recognize the power differential between men and women that takes so many forms in society: legal, economic, and professional, among others.

Hostile work environment is the "harder issue" in sexual harassment cases, for several reasons. First, hostile work environment claims are problematic in that offenders are often co-workers or others who have no formal, recognized authority over the victim, often triggering an assumption that the offender is not in a position to harm the victim. Consequently, some courts may assume that no harm has occurred, failing to recognize the non-neutrality of the existing gender-hierarchy.

Pollack, supra note 4, at 50-51 (footnote omitted).

54. See 29 C.F.R. § 1604.11(b) (1991); see supra note 3.

55. Although it cannot hold an employer hable for the evils of society, so to speak, 
When sexual harassment occurs in the workplace there are two axes of power to consider: that inherent in the employer/employee relationship and the societal imbalance of power that currently exists between men and women.

\section{The Effect of Gender Stereotypes on Popular Perception}

Gender stereotypes affect the way we view sexual conduct by men and the sexual receptivity of women. As in the context of rape, female victims of sexual harassment are often perceived as "asking for it" or inviting the alleged harassment by the way they dress, speak, or act. In Meritor Savings Bank v. Vinson, ${ }^{56}$ the Supreme Court defined one prong of its standard as an evaluation of whether or not the female plaintiff initially welcomed the attentions she later labelled harassment. In its discussion of the "voluntariness" issue, the Court clarified that a woman who voluntarily sleeps with her supervisor in order to keep her job does not necessarily "welcome" the conduct-and does not forfeit her claim of harassment. But the Court did allow evidence regarding the victim's manner of dress, speech, and conduct to determine whether she did in fact "welcome" the advances. Depending on the trier of fact, the elicitation and use of this type of evidence may re-victimize the victim, making it effectively impossible for a woinan to succeed on a claim: ${ }^{57}$

a court does have the power to consider how the cultural norms of our society impact the dynamics of the working environment and the harm resulting from sexually harassing incidents that take place within that cultural context.

56. 477 U.S. 57 (1986).

57. In the context of rape, evidence of this nature is often prohibited by rape shield laws. The victim's prior sexual relationship with the alleged perpetrator would always be relevant, but her past sexual life is generally protected. See, e.g., N.C. GEN. STAT. $\S 8 C-1$, Rule 412 (1988). By inaking the mamier in which a victim of sexual harassment dresses and speaks relevant, the Meritor Court places the evidence in the first category, assuming a relevant relationship with the defendant and implicitly suggestimg that the woman dressed or spoke in a certain way for that person. This interpretation is the only one that can validate the Court's ruling. It would be unreasonable to say that a woman who dresses in an "objectively" provocative manner-if such a thing could ever be defined-welcomes conduct of a sexual nature from all men in her immediate working environment. The difficulty of assessing what kind of dress qualifies as "provocative," combined with the unfairness of the presumption that if a woman dresses provocatively she is doing it for the benefit of a particular man (i.e., to invite his sexual advances), renders the Court's holding on the issue both unwise and skewed in the favor of the defendant. For further discussion of the "unwelcomeness" standard, see supra note 29. 
While "voluntariness" in the sense of consent is not a defense to such a claim, it does not follow that a complainant's sexually provocative speech or dress is irrelevaut as a matter of law in determining whether he or she found particular sexual advances unwelcoine. To the contrary, such evidence is obviously relevant. $^{58}$

The definition of "provocative" varies with the diversity of the defining audience. Gender stereotypes shape these definitions for many people. The way a "lady" should look, act, dress, and speak often works against sexual harassment victims who do not conform to the norms offered by traditional and contemporary stereotypes. ${ }^{59}$ By leaving the word "unwelcome" open to such broad interpretations by lower courts, the Supreme Court in Meritor establishes a standard that is potentially debilitating to plaintiffs.

Our societal expectations about gender role conformity extend to men as well as to women. "Boys will be boys" and "Men will be men" are possibly two of the most popular quips used to justify and rationalize male sexual behavior. Traditional sexual lore perpetuates the idea that men are supposedly more sexual animals than women: There is a popular notion that men just can't help themselves when it comes to sex, and that women are responsible for controlling men's behavior. ${ }^{60}$ "Scholarly" articles have offered this biologically based myth as a fact that ought to govern the remedies and legal responses to sexual harassment: "[W]omen have a responsibility not to encourage males to make sexual advances. This can be done by refraining from acting in a flirtatious or sexually inviting manner, dressing in a sexually provocative manner or talking in a manner that would welcome sexual advances." 61

This statement relies on the Supreme Court's language in Meritor to bolster the purportedly rational solution to the problem of sexual harassment: "It would not be unreasonable to conclude

58. Meritor, 477 U.S. at 69.

59. For an example of the way in which gender stereotypes about the way a "lady" should look, act, walk, and talk, become relevant in sexual discimination cases, see Price Waterhouse v. Hopkins, 490 U.S. 228 (1989).

60. TIMOTHY BENEKE, MEN ON RAPE 125 (1982) (A psychoanalyst and family therapist in Atlanta discusses women who "invite rape": "Women have the capacity to arouse a man-there's no question about that. And once the man gets involved, once the sexual motor gets going, the sexual drive may take over.").

61. Murray, supra note 43 , at 483 . 
that where a woman clad herself in sexually provocative clothing, acted and spoke in a provocative manner, or otherwise indicated she may have been interested in a sexual relationship, sexual advances were not unwelcome." ${ }^{22}$ Neatly undermining a plaintiff's claim of sexual harassment with undue and entirely subjective emphasis on unwelcomeness, the statement offers "provocative," "flirtatious," and "sexually inviting" as if these were objective realities susceptible to scientific determination. There is no objective understanding of the word "provocative." The judge, the victim, the perpetrator, and commentators will all have different understandings based on their different experiences and perspectives. This common idea that women are somehow responsible for controlling men's sexual beliavior deflects the responsibility from the male perpetrator onto the female victim. Such recommendations to women specifically support the notion that if women dress in a certain way, men will not be able to control themselves-i.e., that women just have to expect what they inevitably get. ${ }^{63}$

The perception gaps between men and women, the power dynamics inherent im a sexual liarassment situation in which a woman is the victim, and popular gender stereotypes are all factors that must be considered in a coherent analysis of a lostile environment sexual harassment claim. Indeed, proponents of the reasonable woman standard argue that the Supreme Court's standard delineated in Meritor has not proven effective in dealing with sexual harassment claims precisely because the reasonable person standard most frequently applied by the lower courts to give meaning to terms such as "severe," "pervasive," "hostile," and

62. Id.

63. Murray reveals the biases that enable the conclusions in other statements throughout the article: "Flirtatious behavior and romantic attraction surely cannot be classified as 'sexual advances' in the sense of harassment." Id. at 473-74. Murray completely misses the overwhelming problem that plagues sexual harassment victims. Behavior that men would classify as romantic or harmless flirtation is often characterized by women as harassing. Murray takes a behavior and characterizes it "objectively" as a flirtation while failing to acknowledge that the perspective used in this process is highly subjective. Murray continues, "In most imstances where insults and sexist comments are the only behavior claimed to be harassing, the victim is overly sensitive to the subject matter of the insult." Id. at 475. This statement is an even more blatant revelation of a complete lack of understanding about the issue of perspective. The exphicit message is that women should not be permitted to recover legally merely because they feel harassed by sexist comments. The fact that Murray beheves the article offers an "objective" victim standard as a solution to the problems posed by sexual harassment cases is the final irony of the piece. 
"abusive" masks these highly relevant factors. The recent cases of Rabidue v. Osceola Refining Co. and Ellison v. Brady illustrate the consequences both of failure to consider the factors of perception and power and, alternatively, of attempts to consider these factors explicitly.

\section{RABIDUE AND ELLISON: THE REASONABLE PERSON AND THE REASONABLE WOMAN}

\section{A. Rabidue v. Osceola Refining Co.: The Reasonable Person Standard and the Apparent Need for a Reasonable Woman's Perspective in the Law}

The traditional reasonable person standard, applied using the vague language of the Meritor standard, does not mandate a rigorous or insightful analysis of the plaintiff's perspective in sexual harassment cases. The Sixth Circuit's manipulation of the Meritor standard in Rabidue v. Osceola Refining $\mathrm{Co}^{64}$ illustrates the standard's susceptibility to debilitating interpretation. Douglas Henry, an employee of Osceola, persistently called his co-worker, Vivienne Rabidue, and other female employees, "whores," "cunt," "pussy," "tits," and "fat ass." He said of Rabidue, "All that bitch needs is a good lay." ${ }^{\prime 65} \mathrm{He}$ and other male employees insisted on displaying pornographic pictures of women in common work areas. ${ }^{66}$ In particular, one picture, displayed for eight years, showed a naked, prone woman with a golf ball on her chest and a man standing over her, golf club in hand, yelling "Fore." than dealing with these facts explicitly, ${ }^{68}$ the majority chose to fo'cus instead on Rabidue's "irascible and opinionated personality and her inability to work harmoniously with co-workers, ${ }^{, 69}$ not

64. 805 F.2d 611 (6th Cir. 1986), cert. denied, 481 U.S. 1041 (1987).

65. Id. at 624 (Keith, J., dissenting). This language was analyzed by the district court as follows: "[P]laintiff's overall work experience was not substantially affected by Mr. Henry's vulgarity. Instead the vulgarity merely constituted an annoying-but fairly insignificant-part of the total job environment." 584 F. Supp. 419, 433 (E.D. Mich. 1984), affd, 805 F.2d 611 (6th Cir. 1986), cert. denied, 481 U.S. 1041 (1987).

66. 805 F.2d at $623-24$.

67. Id. at 624 .

68. It is interesting to note that neither the district court nor the Sixth Circuit explicitly and accurately state the facts of the case. They do not even attempt to describe the aspects of the working environment that Vivienne Rabidue found offensive. The facts of the record are only fully revealed in Judge Keith's dissent to the Sixth Circuit opinion.

69 . 805 F.2d at 615. 
analyzing in the least how these personality traits may very well have been exacerbated, if not caused, by the hostile working environment she was subjected to on a daily basis. ${ }^{70}$

The Sixth Circuit majority, using the reasonable person standard, concluded that Henry's obscenities, "although annoying, were not so startling as to have affected seriously the psyches of the plaintiff or other female employees."71 The majority relied on the analysis of the district court: "As Judge Newblatt aptly stated .... : 'Indeed, it cannot seriously be disputed that in some work environments, humor and language are rough hewn and vulgar. Sexual jokes, sexual conversations and girlie magazines may abound. Title VII was not meant to-or can [sic]-change this." "72

The court applied a two-part test: 1) a reasonable person must be adversely affected by the alleged sexual harassment; and 2) the plaintiff must show that she was actually offended. The first prong of the test establishes the unreasonableness of the conduct. The second prong is suspect in that it does not add anything to the investigation of the conduct at issue and merely gives the court an opportunity to put the plaintiff on trial by examining her personal background, sexual history, and manner of dress and speech. ${ }^{73}$ Effectively, the second prong of the test asks the victim whether she is, in fact, a reasonable person. Interestingly, conduct deter-

70. Commenting on Rabidue, Lucinda Finley writes:

This description of the facts trivialized the conduct and placed a subtle suggestion of blame on the victim: knowing poor Henry was vulgar, Rabidue should have done something to reduce the acrimony, she should have known that men used bad language and had the posters displayed, and thus she voluntarily encountered her problems and assumed the risk of working in the environment.

Clearly, the manner in which a court characterizes the facts, what it chooses to focus on, and what it leaves unmentioned, can be part of gender bias.

Finley, supra note 8 , at $61 \mathrm{n} .65$ (citations omitted).

71. $805 \mathrm{~F} .2 \mathrm{~d}$ at 622 . This statement offers one of the most valuable insights into the importance of perspective. See supra Section II(A).

72. Rabidue, 805 F.2d at 620-21 (quoting 584 F. Supp. at 430); see also Katz v. Dole, 709 F.2d 251, 256 (4th Cir. 1983) ("Title VII is not a clean language act, and it does not require employers to extirpate all signs of centuries-old prejudices."). The Rabidue opinions are "noteworthy for their suggestion that sexual innuendo or pornography is simply a stronger form of 'rough manners' .... [T] he gently dismissive term 'girlie magazines' suggest[s] an almost amused tolerance that reflects no awareness of how female plaintiffs might perceive these affronts." Abrams, supra note 31, at 1201.

73. Justice Rehnquist would argue that this type of investigation enables the court to discern whether the conduct was unwelcome. See Meritor Sav. Bank v. Vinson, 477 U.S. 57, 69 (1986); supra note 58 and accompanying text. 
mined to be racially offensive to a reasonable person in the context of racial discrimination is presumed to offend the victim: Victims of racial discrimination are not subjected to the second prong of the Rabidue test in the Sixth Circuit. ${ }^{74}$

Writing for the Rabidue majority, Judge Krupansky stated that it is appropriate to assess whether the plaintiff voluntarily entered a working environment where she could reasonably expect to find lewd or off-color humor and behavior. ${ }^{75}$ Judge Krupansky's reading of voluntariness strips Title VII of any effectiveness whatsoever. ${ }^{76}$ Title VII is specifically intended to protect people from being forced to work in degrading, offensive, and debilitating environments. "Congress designed Title VII to prevent the perpetuation of stereotypes and a sense of degradation which serve to close or discourage employinent opportunities for women." RT Rabidue's standard merely serves to entrench further the existing sexist status quo by severely liniting women's opportunities to enter and work successfully within traditionally male-dominated workplaces and professions.

The reasonable person standard, when based on a male perspective, effectively reinforces the status quo or the societal norm. Often, these norms will not be hospitable to women. The Rabidue court illustrated this point vividly in its discussion of pornography. The majority attempted to justify allowing pornographic displays in

74. In racially hostile environment claims brought in the Sixth Circuit, only the first part of the test is required. The conduct must merely be unreasonable or affect a reasonable person's ability to perform her job. It is assuined that plaintiff would be offended by that conduct. See generally Lisa Rhode, Note, The Sixth Circuit's Double Standard in Hostile Work Environment Claims: Davis v. Monsanto Chemical Co., 858 F.2d 345 (6th Cir. 1988), 58 U. CIN. L. REV. 779, 799-801 (1989).

75. 805 F.2d at 620 . As the dissent noted, "The majority suggests through these factors that a woman assumes the risk of working in an abusive, anti-female environment." 805 F.2d at 626 (Keith, J., dissenting).

76. As the Meritor Court recognized, voluntariness is not the appropriate focus of the inquiry in sexual harassment claims. Meritor, 477 U.S. at 68 . A woman may voluntarily participate in sexual conduct if she feels it is necessary to keep her job. The Meritor Court stated that the proper inquiry is whether the complamant welcomed the allegedly offensive sexual conduct. Id. In Rabidue, Judge Krupansky's use of the "voluntariness" concept is extremely debilitating to plaintiffs and is not in accord with the purpose of Title VII. Women voluntarily enter many working environments because they have to-to earn money and to support families. According to Meritor, the appropriate inquiry is whether, once a woman is within a particular working environment, she indicates, by her conduct, that sexual advances are unwelcome. Id.

77. Andrews v. City of Philadelphia, 895 F.2d 1469, 1483 (3d Cir. 1990). 
the workplace by noting that they are, after all, an integral part of American society:

The sexually oriented poster displays had a de minimis effect on the plaintiff's work environment when considered in the context of a society that condones and publicly features and commercially exploits open displays of written and pictorial erotica at the newsstands, on prime-time television, at the cinema, and in other public places. ${ }^{78}$

The poster featuring a man teeing off on a woman's bare chest is not, under any "reasonable" definition of the word, "erotic." This is not a mere picture of a naked body or an erotic sex act. $^{79}$ It is an example of violent pornography. The district court argued, in effect, that the pornography and vulgar language had a "de minimis effect" because Vivienne Rabidue should not

78. Rabidue, 805 F.2d. at 622 (emphasis added). This illogical analysis is based on the fallacious assumption that women are not offended or intimidated by the pornography mundating American society. Women are not the primary consumers of pornography, but activists' intensive efforts to restrict and ban pornography have not been successful to date. Judge Krupansky's analysis essentially used a pornographic society, in which women do not have power to eliminate the offensive material, to justify a workplace in which women are equally powerless. But see Andrews, 895 F.2d at 1485-86 ("Obscene language and pornography quite possibly could be regarded as 'highly offensive to a woman who seeks to deal with her fellow employees and clients with professional diguity and without the barrier of sexual differentiation and abuse.' ... Although men may find these actions harmless and innocent, it is highly possible that woinen may feel otherwise.") (citations omitted); Rabidue, 805 F.2d at 627 (Keith, J., dissenting) ("The presence of pin-ups and misogynous language in the workplace can only evoke and confirm the debilitating norms by which women are primarily and contemptuously valued as objects of male sexual fantasy.").

79. Gloria Steinem's essay Erotica v. Pornography provides a thoughtful commentary on the differences between these two types of sexual imagery. Steinem describes erotica as images of people making love. Nudity is clearly a factor, but she stresses that the people are there because they want to be-mutually sharing a sexual experience. On the other hand, there are images of sex

in which there is force, violence, or symbols of unequal power . . . They may be ... subtle: the use of class, race, authority, or just body poses to convey conqueror and victim; unequal nudity, with one person's body exposed and vulnerable while the other is armored with clothes....

These two sorts of images are as different as love is from rape, as dignity is from humiliation .... Y Yet they are confused and lumped together as... "erotica" or "explicit sex," because sex and violence are so dangerously intertwined and confused.

Gloria STEINEM, Erotica v. Pomography, in OUtrageous Acts and Everyday REBELLIONS 219, 219-20 (1983). In view of this definition, suffice it to say that the Rabidue court's characterization of the violent pornography as erotica may be slightly, if not radically, unisleading, particularly to those individuals trying to assess the effects the pornography was likely to have on Vivienne Rabidue. 
have been legally offended by the pornography, and because the language, although annoying, was insiguificant. Thus, the district court distinctly used the fact that we have a sexist society to justify the acceptability of a sexist workplace. ${ }^{80}$ Following the district court's example, the Sixth Circuit demonstrated that Title VII is clearly not legislation "designed to bring about a magical transformation in the social mores of American workers."

The Rabidue court assumed that because pornography is readily available on the newsstands, women could not possibly be highly offended by it in the working environment. This is not an example of logical reasoning. The better-reasoned argnment would acknowledge that pornography is so widely available precisely because men provide a market for it, ${ }^{82}$ regardless of women's perceptions or opinions about the material. Using the "average" or "reasonable" male's perspective on pornography, then, denies the typical female perspective. By labelling the applied standard that of the reasonable person, the male perspective is presented as representative of women as well. The use of this "gender-neutral" legal standard thus has the effect of denying the female perspective and reinforcing the male-oriented status quo.

Meritor held that hostile environment sexual harassment is actionable under Title VII if the alleged conduct is sufficiently severe or pervasive so as to alter the conditions of the victim's employment and create an abusive working environment. ${ }^{83}$ But Meritor provided the individual judges with an immense amount of interpretive freedom. Thus, as Rabidue illustrates, lower courts

80. Nancy S. Ehrenreich, Pluralist Myths and Powerless Men: The Ideology of Reasonableness in Sexual Harassment Law, 99 YALE L.J. 1177, 1205 (1990).

In equating "reasonableness" with societal consensus (that is, in defining discrimination as deviation from the status quo), the Rabidue [appellate] court (like all courts using this definition of reasonableness) necessarily assumes that the status quo itself is egalitarian, pluralistic, and nondiscriminatory .... [T]he Rabidue majority implicitly assumed that sexual discrimination is merely deviant behavior by individuals, rather than a structural problem inherent in American Id. ideology and institutions.

81. Rabidue v. Osceola Ref. Co., 584 F. Supp. 419, 430 (E.D. Mich. 1984), affd, 805 F.2d 611 (6th Cir. 1986), cert. denied, 481 U.S. 1041 (1987).

82. Most of the pornography on the market is directed at a male audience-both heterosexual and homosexual. Even magazines like Playgirl, which are ostensibly for women, have a significant male audience.

83. Meritor Sav. Bank v. Vinson, 477 U.S. 57, 73 (1986). 
have illiberally construed the Meritor decision. ${ }^{84}$ Fortunately, however, not all courts have used this power so irresponsibly.

\section{B. Ellison v. Brady: The Argument for Adopting a Reasonable Woman Standard}

Some courts have tried to fashion a test that allows for the equal consideration of the perspectives of both the perpetrator and the victim. ${ }^{85}$ Other courts, like the Ninth Circuit in Ellison $v$. Brady, ${ }^{86}$ have adopted a reasonable woman standard. ${ }^{87}$ The jurisdictions that have followed Ellison's reasoning believe that the "reasonableness" aspect of the reasonable woman standard will shield employers from having to accommodate the idiosyncratic concerns of the hypersensitive employee. ${ }^{88}$ Proponents of the reasonable woman standard argue that its "woman" aspect provides a more accurate assessment of what conduct and language is sexually offensive to women, thereby preventing the enforcement of the often sexist status quo-which is exactly what women are trying to

84. As Abrams notes:

In evaluating these claims, courts often must choose between the conflicting views of the alleged harassment. Because most judges are men, who have experienced the traditional forms of male socialization, their instinctive reaction is to accept the perspective of the employer .. ... [A] characteristically "male" view, which depicts sexual taunts, inquiries or magazines as a comparatively harmless amuseinent, or as the treatment women should expect when they push their way into the workplace, pervades many recent opimions.

Abrams, supra note 31, at 1203 (footnote omitted).

85. See, e.g., Lipsett v. University of Puerto Rico, 864 F.2d 881, 898 (1st Cir. 1988) ("Unless the fact finder keeps both the man's and the woman's perspective in mind, 'defendants as well as the courts [will be] permitted to sustain ingrained notions of reasonable behavior fashioned by the offenders.' ") (alteration in original) (quoting Rabidue v. Osceola Ref. Co., 805 F.2d 611, 626 (6th Cir. 1986) (Keith, J. dissenting), cert. denied, 481 U.S. 1041 (1987)).

86. 924 F.2d 872 (9th Cir. 1991).

87. Id. at 878. The Sixth Circuit rejected its Rabidue rationale in favor of the reasonable woinan standard in Yates v. Avco Corp., 819 F.2d 630 (6th Cir. 1987):

[I]t seems only reasonable that the person standing in the shoes of the employee should be "the reasonable woman" since the plaintiff in this type of case is required to be a meinber of a protected class and is by definition female .... Were this a sexual harassment case involving a male subordinate, the "reasonable man" standard should be applied. We acknowledge that men and women are vulnerable in different ways and offended by different behavior.

Id. at $637 \&$ n.2.

88. See Ellison, 924 F.2d at 879; see also Rabidue v. Osceola Ref. Co., 805 F.2d 611, 626 (6th Cir. 1986) (Keith, J., dissenting) ("I would have courts adopt the perspective of the reasonable victim which simultaneously allows courts to consider salient sociological differences as well as shield employers from the neurotic complainant."), cert. denicd, 481 U.S. 1041 (1987). 
escape, at least while they are within the confines of the workplace. $^{89}$

1. Ellison v. Brady. In Ellison v. Brady, ${ }^{90}$ Kerry Ellison, an agent for the Internal Revenue Service, found herself in an uncomfortable, frightening situation with a co-worker, Sterling Gray. At her San Mateo, California office, it was customary for co-workers to go to lunch together, often in groups. One day, when no one else was in the office, Ellison accepted Gray's invitation to lunch. Following this occasion, Gray began to "hang around" Ellison, "pester[ing] her with unnecessary questions." ${ }^{91} \mathrm{He}$ asked her out on dates which she declined. He finally wrote Ellison a note: "I cried over you last night and I'm totally drained today. I have never been in such constant term oil [sic]. Thank you for talking with me. I could not stand to feel your hatred for another day." 92 Extrennely disturbed, Ellison spoke with her supervisor, who labelled Gray's conduct sexual harassinent. Ellison said she would like to try to handle the situation herself, and she had a male co-worker ask Gray to leave her alone. Gray was not daunted. Even after Ellison transferred to Missouri for a four-week training period, he sent her a typed, single-spaced, three-page letter.

I know that you are worth knowing with or without sex .... I have enjoyed you so much over these past few months. Watching you. Experiencing you from $O$ so far away. Admiring your style and elan .... Don't you think it odd that two people who have never even talked together, alone, are striking off such intense sparks . . . I will [write] another letter in the near future. ${ }^{93}$

89. In Rabidue, Judge Krupansky took the position that the reasonable person standard could accomplish both of these goals. It is theoretically possible that a "truly" reasonable judge may be able to provide protection for victims using the reasonable person standard. The majority's skewed reasoning, however, afforded Vivienne Rabidue absolutely no protection. Also, practically discerning the "objectively" reasonable decision begs the question in this context. See Abrams, supra note 31, at 1203 ("Hostile environment doctrine must begin from an understanding of the way in which those practices challenged as sexual harassment are likely to be experienced differently by women than by men.").

90. 924 F.2d 872 (9th Cir. 1991).

91. Id. at 873 .

92. Id. at 874 .

93. Id. (alteration in original). 
Alarmed by Gray's persistence and obstinance, Ellison was afraid of what he might do to her. She filed a formal complaint with the IRS and asked her supervisor to take remedial action. As a result, Gray was assigned to another California location. Six months later, when she was notified that he was to return to the San Mateo office, Ellison once again became worried. The Treasury Department did not believe that Ellison's complaint alleged conduct covered by the EEOC guidelines, and the EEOC felt that a six-month transfer was an adequate remedy. Having exhausted her nonlegal resources, Ellison filed a formal sexual harassment complaint. The district court held that Ellison did not establish a prima facie case: Ellison's allegations did not indicate an environment sufficiently severe and pervasive to alter the conditions of the workplace or to create an abusive atmosphere. The court believed, rather, that Gray's conduct was "isolated and genuinely trivial," 94 and thereby granted the government's motion for summary judgment. On appeal, the Ninth Circuit adopted the reasonable woman standard, reversing and remanding the trial court's decision.

The Ninth Circuit applied Meritor's standard regarding the pervasiveness and severity of abusive behavior, but added a protective measure for the female plaintiff by substituting the perception of a reasonable woman for that of a reasonable person. The court held that a "female plaintiff states a prima facie case of hostile environment sexual harassment when she alleges conduct which a reasonable woman would consider sufficiently severe or pervasive to alter the conditions of employment and create an abusive working environment." El Ellison met this standard because the court found that "[a] reasonable woman could consider Gray's conduct, as alleged by Ellison, sufficiently severe and pervasive . . . .96 Judge Beezer explained the court's rationale:

If we only examined whether a reasonable person would engage in allegedly harassing conduct, we would run the risk of reinforcing the prevailing level of discrimination. Harassers could continue to harass merely because a particular discriminatory practice was common, and victims of harassment would have no remedy.

94. Id. at 876 .

95. Id. at 879 (footnote omitted).

96. Id. at 880 . 
We therefore prefer to analyze harassment from the victim's perspective. A complete understanding of the viction's view requires, among other things, an analysis of the different perspectives of men and women. Conduct that many men [would] consider unobjectionable may offend many women. ${ }^{97}$

2. Arguments Offered by Proponents of the Reasonable Woman Standard. Proponents of the reasonable woman standard argue that "[h]ostile environment doctrine must begin from an understanding of the way in which those practices challenged as sexual harassment are likely to be experienced differently by women than by men." ${ }^{98}$ Even though there inay be substantial differences among women, there are yet greater differences between women and men due to social factors.

While many woinen hold positive attitudes about uncoerced sex, their greater physical and social vulnerabihity to sexual coercion can make women wary of sexual encounters. Moreover, American women have been raised in a society where rape and sexrelated violence have reached unprecedented levels, and a vast pornography industry creates continuous inages of sexual coercion, objectification and violence. Finally, women as a group tend to hold more restrictive views of both the situation and the type of relationship in which sexual conduct is appropriate. Because of the inequality and coercion with which it is so frequently associated in the minds of women, the appearance of sexuality in an unexpected context or setting of ostensible equality can be an anguishing experience.99

Additionally, proponents of the reasonable woman standard illustrate the political nature of the judgments courts make in sexual harassment cases by emphasizing these societally constructed differences between men and women. ${ }^{100}$ They reject the tradi-

97. Id. at 878 .

98. Abrams, supra note 31, at 1203.

99. Id. at 1205 (footnotes omitted).

100. I use the word "political" in this context to mean that women's rights and autonoiny as citizens within the state can be severely compromised when women are subjected to an ostensibly gender-neutral standard in a society hierarchically structured along gender lines. The neutrality and objectivity that are the goals of such a standard are necessarily illusory in this context. The traditional reasonable person standard has the tendency to assume the equality of both parties. The reasonable woman standard highlights both the political situation that creates this illusion as well as the political consequences (for all women) of the decisions rendered in these cases (brought by individual women). Es- 
tionalist torts approach that balances the rights of two individuals-the man's right to free speech and conduct against the woman's right to work unmolested and unoffended. ${ }^{101}$ This balancing approach is considered meffective because it assumes the equal positioning of the parties-both socially and in the working environment. Regardless of the theoretical equality of all people, women, both historically and currently, do not have as much social, political, or economic power as men do in this country. ${ }^{102}$ In effect, women as a group have less decisionmaking power in the workplace and, therefore, less control.

Civil rights legislation has enabled women to seek decisionmaking power and a measure of control within the workplace where it has been unlawfully denied. Under Title VII, women cannot be turned away, because of their sex, from jobs for which they are otherwise qualified. Proponents of the reasonable woinan standard may argue cogently that equal access to the workplace does not always translate into equal freedoin and power within the workplace, and that nothing precludes Title VII from being utilized to redress oppressive and discriminatory working conditions where they exist. The argument can be constructed as follows: In a perfect society, inen and woinen with equal power, control, and freedoin may not view sex and sexual conduct differently. In our imperfect society, however, men and woinen are victims of social-

sentially, a sexual harassment case is political in that it does not merely concern the rights of two parties. It is political in that a complaint brought by one woman, and the treatment that complaint receives within the judicial system, may reflect on and entail consequences for the larger group of "women."

101. See generally Paul, supra note 2.

102. The political inequality stems from the fact that representation in both federal and local government, although it is improving, is still far from representative of the proportion of women in the country. As of November 1992, there are 48 women of 435 members of the U.S. House and 6 women of 100 U.S. Senators. Phil Duncan, Looking Beyond Gridlock, in CONGREsSIONAL QUARTERLY SPECIAL REPORT: THE NEW CONGRESS, Jan. 16, 1993, at 11, 12. Economically, women are still largely represented in lowskill, underpaid, undervalued jobs, resulting in further imequities. See supra note 47. Wage disparity is also a factor. Women continue to be paid significantly less than their male counterparts. See STATISTICAL ABSTRACT, supra note 46, at 412, 452-53. In this country, more than three-quarters of the people hiving under the poverty level-77.9\%-are women and children under the age of eighteen. See U.S. Bureau of the Census, Poverty in the United States: 1991 (Current Population Reports, Series P-60, No. 181, U.S. Gov't Printing Office, Washington, D.C., 1992). The social inequality of women results from a combination of these economic and political factors and traditional notions, influenced by gender stereotypes, of acceptable women's roles-in the family, in a marriage, as mothers, and in the workplace. 
ization, and often perceive sexual conduct differently. The instances of sexual harassment attributable to these different ways of perceiving sexual conduct cannot be addressed effectively with a purportedly gender-neutral standard based on the perception of the reasonable person. Such a standard serves only to mask the essential political nature of the reasonableness question and the societal inequahty of women that underlie the problem of sexual harassment. The Ellison majority's language reflects the reasoning behind this argument:

Men, who are rarely victims of sexual assault, may view sexual conduct in a vacuum without a full appreciation of the social setting or the underlying threat of violence that a woman may perceive.

We adopt the perspective of a reasonable woman primarily because we believe that a sex-blind reasonable person standard tends to be male-biased and tends to systematically ignore the experiences of women. ${ }^{103}$

Although it shares some problems with the reasonable person standard, ${ }^{104}$ the reasonable woman standard calls for an explicit recognition of the fact that the choice between plaintiff and defendant in sexual harassment cases may be a political one involving group dynamics as well as individual rights.

Furthermore, the reasonable woman standard helps negotiate the distance between the judge as decisionmaker and the plaintiff or defendant as the beneficiary of that decision by illuminating potential biases. In sexual harassinent cases, almost all of the defendants are men, and almost all of the plaintiffs are women. A male judge may identify with the male defendant's perspective more readily than with the female plaintiff's. The reasonable woman standard may encourage a male judge to realize that his tendency to view the man's account of the facts as credible and the female complainant's as hypersensitive may result froin a socialization process that resembles the man's as opposed to the woman's.

In evaluating these claims, courts often must choose between the conflicting views of the alleged harassment. Because most judges

103. Ellison v. Brady, 924 F.2d 872,879 (9th Cir. 1991).

104. See infra text accompanying note 112-24. 
are men, who have experienced the traditional forms of male socialization, their instinctive reaction is to accept the perspective of the employer .... [A] characteristically "male" view, which depicts sexual taunts, imquiries or magazines as a comparatively harmless amusement, or as the treatment women should expect when they push their way into the workplace, pervades many recent opimions. It is present in the indulgent attitudes courts display toward these forms of conduct, in their confusion of harassment with profanity or rough mauners, and in their reluctance to credit the accounts of fenale plaintiffs. ${ }^{105}$

Judge Beezer illustrated this perception gap problem using the Ellison facts:

[F]rom the alleged harasser's viewpoint, Gray could be portrayed as a modern-day Cyrano de Bergerac wishing no more than to woo Ellison with his words. There is no evidence that Gray harbored ill will toward Ellison .... .

Ellison, however, did not consider the acts to be trivial. Gray's first note shocked and frightened her. After receiving the three-page letter, she became really upset and frightened again. ${ }^{106}$

Identifying with the "characteristic male view," the district court was reluctant to credit Ellison's account and found Gray's conduct genuinely trivial. But the appellate court, cognizant of the perception gap problem, rejected the district court's finding.

The reasonable woman standard has illuminated the perception gap among men and women on the sensitive issue of sexual harassment, the political nature of judgments in sexual liarassment cases, and the susceptibility of the more traditional reasonable person standard to potential socialized "male" bias. Although deference to the female victim's perspective has enabled these realizations, the Ninth Circuit's innovative legal standard has engendered concern on the part of potential defendants regarding the fairness of a standard that seems to assign fault to an individual man on the basis of an offense he did not intend to commit. In many cases, as illustrated im Part II above, a woman may perceive sexual conduct as liarassing when the man involved in no way intended to harass her. But legally, harassment can exist without intent. The standard adopted by the Ellison majority

105. Abrams, supra note 31 , at 1203.

106. Ellison, 924 F.2d at 880 (citation omitted). 
classifies conduct as unlawful sexual harassment even when harassers do not realize that their conduct creates a hostile working environment. Well-intentioned compliments by co-workers or supervisors can form the basis of a sexual harassment cause of action .... That is because Title VII is not a fault-based tort scheme. "Title VII is aimed at the consequences or effects of an employment practice and not at the . . . motivation" of co-workers or employers. ${ }^{107}$

Hostile working environments detrimentally affect female employees' ability to work confidently, comfortably, and unmolested. ${ }^{108}$ The reasonable woman standard focuses on women's perceptions and can be used to remedy forms of harassment that women feel unreasonably interfere with their work performance. ${ }^{109}$ It does not, however, assign fault to individual men for not intuitively discerning women's different sensibilities. A successful harassment claim can be levelled at an employer who has failed to take action after a woman has complained to the management. The employer who does not take action is at fault for passivity in the face of a known problematic situation. In light of this situation, the use of a reasonable woman's perspective encourages employers to create grievance procedures and to consider carefully harassment complaints made by female employees from their point of view. The Ellison majority believed the reasonable woman standard would raise the general consciousness about sexual harassment: "We hope that over time both inen and women will learn what conduct offends reasonable members of the other sex. When employers and employees internalize the standard of workplace conduct we establish today, the current gap in perception between the sexes will be bridged."110

The reasonable woman standard offered by the Ninth Circuit allows courts to factor the woman's perspective into the legal

107. Id. (quoting Rogers v. EEOC, 454 F.2d 234 (5th Cir. 1971), cert. denied, 406 U.S. 957 (1972)).

108. See Susan E. Martin, Sexual Harassment: The Link Joining Gender Stratification, Sexuality, and Women's Economic Status, in WOMEN: A FEMINIST PERSPECTIVE 57, 62 (Jo Freeman ed., 4th ed. 1989). Martin enumerates some of the detrimental effects reported to result from incidents of sexual harassment, including: humiliation, shame, anger, ahenation, aloneness, helplessness, guilt, strained relations with men (including husbands), and loss of ambition and self-confidence, as well as negative views of work.

109. However, under this standard the harassment still has to be pervasive and severe.

110. Ellison, 924 F.2d at 881 . 
analysis of sexual harassment claims. Although people acknowledge the proposed differences between men and women either intuitively or reasonably as a consequence of socialization processes, many challenge this proposition on two levels. First, some people do not accept the idea that men and women can be placed into the discrete categories suggested by the foregoing analysis. Second, women are very different from one another; many women reject being lumped into a group labelled "women" and assigned the viewpoint of relative powerlessness. This latter challenge exposes a fundamental problem with the reasonable woman standard: Who is she? Is she somehow the average or median of all women? ? $^{111}$ What do women sacrifice or gain by being represented by this fictional, contrived entity?

\section{THE REASONABLE WOMAN STANDARD Has PROBLEMS OF ITS OWN}

The problems mherent in the reasonable woman standard proposed by the Ellison court are certainly not as extreme as those illustrated by the Rabidue court's effective annihilation of the sexual harassment claim as a viable option for women. However, definitional, theoretical, and practical aspects of the reasonable woman standard render it an ineffective and potentially harmful reform. This Part outlines the reasonable woman standard's problem areas: the difficulty in defining a reasonable woman; the marginalization that mevitably results from the development of a separate legal standard of "reasonableness" peculiar to women; the reification of difference through the implementation of a standard based on that difference; and, on a practical level, the susceptibility of this new standard to the old problems of perception and bias. Although some of these problems inhere in one or more of the alternative standards, this particular combination of problems posed by the reasonable woman standard causes the known costs of the suggested reform to outweigh its potential benefits.

111. These definitional problems do not seem insurmountable, however, and women may be better served by the perspective of the average woman than of the average inan. "We realize that there is a broad range of viewpoints among women as a group, but we believe that many women share common concerns wlich men do not necessarily share." Ellison, 924 F.2d at 879 . Pollack points out that it is necessary to focus, not only on the woman's perspective, but also on the woman's experience within a gendered hierarchy. Pollack, supra note 4, at 70 n.134; see infra Section IV(A). 


\section{A. The Definitional Quandary}

The reasonable woman standard replicates some of the faults of the reasonable man or person standard. ${ }^{112}$ As one scholar notes, the dissent to the Sixth Circuit's majority opinion in Rabidue v. Osceola Refining Co ${ }^{113}$ depicted the reasonable woman standard as "a neutral construct" that "itself will determine whether a particular woman's complaint is legitimate."114 As the following discussion demonstrates, this neutrality is somewhat illusory. Judge Keith's dissent in Rabidue highlights the most problematic aspect of the reasonable woman standard: A reasonable woman is difficult to define. "[T]he dissenter views the reasonable woman test as distinguishing between regulable 'neurotic' women and protected 'reasonable' women. And just as the majority uses consensus as the neutral mediator between diversity and conformity, so the dissent uses consensus among women as a similar mediator." 115

Over the years, a substantial amount of criticism has been directed at both the historical and the modern women's movements for being predominantly white and upper-middle class and for having a predominantly white, upper-middle-class agenda. ${ }^{116}$ Critics may argue legitimately that, in its application, any reasonable woman standard will inevitably reflect this white, upper-middle-class bias and, therefore, produce a skewed understanding of what women, as a group, identify as offensive sexual conduct. Be-

112. See Ehrenreich, supra note 80, 1215-19. Ehrenreich illustrates some of the drawbacks of a reasonable woman standard; but most of these drawbacks stem from problems with reasonableness as much as they do from "womanness."

113. 805 F.2d 611 (6th Cir. 1986), cert. denied, 481 U.S. 1041 (1987).

114. Ehrenreich, supra note 80 , at 1216-17.

115. Id. at 1217. It is the viability of this group-wide consensus that many women reject. Imagine the following group of women discussing sexual harassment at a roundtable discussion: Gloria Stemem, Camille Paglia, Anita Bryant, Catharine MacKinnon, Sandra Day O'Connor, and Marilyn Quayle. It is possible that this particular group of women would never reach a consensus. One member of the group would clearly object to an opposing inember's viewpoint being labelled as the "reasonable" woman's perspective. Expecting a woman to be able to speak on behalf of all women simply by virtue of her sex is subject to criticism as an essentialist position.

116. A current example of this bias can be secn in the "Pro-Choice" moveinent. The main einphasis of the women's moveinent in the area of abortion has been the freedom of a woman to make decisions concerning her own body and the mappropriateness of the current role of government in that decision. Unfortunately, for many poor, young, and/or minority women, government involvement in the form of federal funding is exactly what is needed to enable their freedom to choose. 
cause more educated women tend to identify more types of sexual conduct in the workplace as sexually harassing, ${ }^{117}$ critics may argue that the use of a more highly educated woman as the standard would produce an unrepresentative number, i.e., too large a number, of successful cases. ${ }^{118}$

To lobby for certain legal reforms in the past, such as suffrage and reproductive rights, women have needed to promote an image of themselves as a group. In essence, women have had to respond as a group because they have been discriminated against in many capacities as a group. From the colonial period through the early twentieth century, women as a group were perceived by men as incompetent to handle the responsibility of voting. ${ }^{119}$ At other times women as a group have been perceived as incompetent to have sole custody of their children ${ }^{120}$ or to practice law. ${ }^{121} \mathrm{Re}$ -

117. Pollack also notes that "reports of sexual harassment increase with a woman's level of education, not only because these women are more likely to be in nontraditional jobs, but also because they define more types of behavior as harassing." Pollack, supra note 4, at 52 n.55 (citing Martin, supra note 107, at 59-60).

118. The danger that the "reasonable" woman would be equated with the most educated woman is unlikely. Highly educated women are a minority aunong women in the work force. See supra note 47. A more realistic danger is that these women, because of their minority status, will be considered unreasonable.

119. In a letter to James Sullivan, dated May 26, 1776, John Adams emphasizes the inadvisability of opening to question the voting qualifications of men without property:

[I] $\mathrm{t}$ is dangerous to open so fruitful a source of controversy and altercation as would be opened by attempting to alter the qualifications of voters; there will be no end of it. New claims will arise; wounen will demand a vote ..... It tends to confound and destroy all distinctions, and prostrate all ranks to one common level.

Letter from John Adams to James Sullivan (May 26, 1776), reprinted in THE FEMINIST PAPERS: FROM ADAMS TO DE BEAUVOIR 13, 15 (Alice S. Rossi ed., 1973). Of women, children and men without property, Adams theorized that these are "too hittle acquainted with public affairs to form a right judgment, and too dependent upon other inen to have a will of their own[.]" Id. at 14. Women, in particular, are unfit for other reasons as well:

[T] heir delicacy renders them unfit for practice and experience in the great businesses of life, and the hardy enterprises of war, as well as the arduous cares-of state. Besides, their attention is so much engaged with the necessary nurture of their children, that nature has made thein fittest for domestic cares.

Id. at 13-14. Fortunately, by 1920,144 years later, women were able to work free of some of these debilitating behiefs.

120. See generally PHYLIIS CHESLER, MOTHERS ON TRIAL: THE BATTLE FOR CHILDREN AND Custody (1986); FAMILY LAW: CASES, TEXT, PRoblems 491-92 (Ira M. Ellman et al. eds., 2d ed. 1991).

121. See Bradwell v. Illinois, 83 U.S. 130 (1872) (Bradley, J., concurring in judgment, joined by Field and Swayne, JJ.) (upholding law forbidding woinen to practice law in light of "their natural and proper timidity" unfitting women for "many of the occupations of civil life"). 
form movements engineered to gain certain rights for all women also had the effect of putting all women in one group-the petitioners, or, alternatively, the victims of oppression.

Woinen's identity as a group then, often utilized in legal fora and in reform efforts, has operated to obscure the individual identities of women and the vast differences among women. Within the context of the women's movement and at times characterized by agitation for various women's rights, questions like "Well Ms. X, what do woinen think about ... ?" have become increasingly common. This phenomenon was readily apparent during Supreme Court Justice Clarence Thoinas's confirmation hearings. The nation's attention turned very briefly to the way women perceived harassment. Reporters and interviewers, however, obtained very different responses froin Phyllis Schlafly than froin Molly Yard and Catharine MacKinnon. ${ }^{122}$ Women froin all over the United States demonstrated their vast diversity of opinion on the subject by calling television news programs with comments ranging from, "Well, even if he did do all those things she said he did, that's not really harassment" to "If a man asks a woinan out after she has said 'no' once, that constitutes sexual harassment." The vastly different perspectives anong women about sexual conduct in the workplace highlight the problems judges may have in discerning the reasonable or representative perspective necessary to apply the reasonable woinan standard.

Another definitional problem posed by the reasonable woman standard concerns its apparent exclusion of men from the class of sexual harassment victims. It is necessary to consider the implications of this standard and its apparent corollary, the reasonable inan standard, for inale victims. In his dissent in Ellison $v$. Brady, ${ }^{123}$ Judge Stephens made a useful point on this topic regarding the inadvisability of adopting a reasonable woman standard. First, while acknowledging woinen's predominance in the

122. “'The feminists always say they speak for women. They don't at all,' fumes Phyllis Schlafly, president of Eagle Forum, a politically conservative group. 'They are like Thelma and Louise. They want to lock the man in the trunk, throw out the keys, and make it a day." Sonia L. Nazario, Views of "Women" Are as Varied as the Women, WALL ST. J., Oct. 18, 1991, at B4. Nazario's article documents various polls that revealed that women were divided over Anita Hill's sincerity and Justice Clarence Thomas's guilt. Notable divisions fell along the lines of age, occupation, socio-economic status, and ideology.

123. 924 F.2d $872,884-85$ (9th Cir. 1991) (Stephens, J., dissenting). 
group of sexual harassment victims, he emphasized the fact that men also experience harassment in the workplace. ${ }^{124} \mathrm{~A}$ reasonable woman standard would not benefit them, and might, in fact, disadvantage them..$^{125}$ The reasonable woman standard is largely a product of the recognition of gender-role stereotyping and its effects on women. If men are held to the standard of the average socialized man, characterized pervasively by the trappings of American machismo, their claims of sexual harassment will not be successful. Certainly, men who experience sexual harassment should be able to bring a claim and have the benefit of a standard that can accommodate men who do not conform to the gender stereotype of the typical, red-blooded American male.

Judge Stephens suggested, among other things, a "victim" standard as an alternative "more in line with a gender neutral approach." 126 The Ellison majority, repeatedly referring to the standard as that of the reasonable woman, undoubtedly did so because it perceived accurately that most victims are women. The majority probably would not have had difficulty adopting Judge Stephens's "victim" terminology, but would not have agreed that gender-neutrality is a good thing. Although the "victim" terminology is a positive change in that men can benefit from the protection it affords, the idea that gender is irrelevant to the analysis is exactly what the Ellison majority tried to dispel: "We adopt the perspective of a reasonable woman primarily because we believe that a sex-blind reasonable person standard tends to be male-biased and tends to systematically ignore the experiences of women."127 The tension is apparent. An attempt to eradicate the negative effects of gender-stereotyping on women by encouraging an explicit focus on

124. Id. at 884 .

125. Judge Beezer, writing for the majority, argued that the "reasonable woman standard does not establish a higher level of protection for women than men." Id. at 879. However, a gender-socialization analysis consistent with that which recommends the reasonable woman standard may, in fact, suggest that men would receive less protection characterized as "men" than they would as "victims." In Yates v. Avco Corp., 819 F.2d 630 (6th Cir. 1987), the Sixth Circuit adopted the reasonable woman standard. The court's acknowledgement that men and woinen are vulnerable to sexual harassinent in different ways and are offended by different behavior could be read to suggest that men are less vulnerable and less susceptible to offense. Applying a "reasonable man" standard to male victims of harassment in this context may make it extremely difficult for a male plaintiff to prevail if he is unlike the average, heterosexual American inale. See supra note 87.

126. Id. at 884 (Stephens, J., dissenting).

127. Id. at 879 . 
what "real woinen" really think runs the risk of subjecting male victins to equally debilitating gender-stereotyping by imposing on these plaintiffs a standard based on what "real men" really think. Just as the educated woman may stand to lose by application of a reasonable woinan standard, a nonconformist man stands to lose from its necessary corollary, the standard of reasonableness designed exclusively for men in harassment situations.

\section{B. Theoretical Drawbacks}

1. A Separate Standard Based on the "Reasonableness" of Women as Distinct from Men Is Inherently Marginalizing. In light of the vast diversity among woinen, and the danger of assigning a uniform viewpoint to all woinen on the basis of their membership in the group "women," the reasonable wornan standard may not be the most effective way to solve the problems it proposes to solve. The definitional drawbacks of the reasonable woman standard outlined above expose the danger of defining women as a subset of humanity with understandings of reasonableness inherently different from those of men. Although the reasonable woman standard seems useful precisely because of differences between men and women created largely by gender-role socialization, establishing a reasonable woman in the law ultinately may have a inarginalizing effect:

[S]ubstituting a reasonable woman standard to judge the conduct of women, but not going further to question the inclusiveness of norms informing the reasonable person standard, implies that women's experiences and reactions are something for women only, rather than normal human responses. Since women are a significant proportion of persons, their experiences should couut as the experiences of a reasonable person, not merely as the experiences of a reasonable woman. ${ }^{128}$

Whether a reasonable woman and a reasonable person standard can coexist is a useful inquiry. ${ }^{129}$ This juxtaposition implies that women are soinehow not persons, a dichotoiny that the law should

128. Finley, supra note 8 , at 64 .

129. In situations concerning sexual harassment victims, the correlative standard for men may be the reasonable man standard as opposed to the inore commonly used reasonable person standard. The problems with this application are outlined above in Section A. 
not establish. This observation provides support for those who believe that the reasonable person standard should be maintained and that the Rabidue court, on the facts presented, made an aberrant, unreasonable decision. According to this reasoning, the inequitable result produced by the Rabidue court should not be the motivating factor for the abandonment of a neutral, reasonable person standard.

The reasonable person standard has, after all, produced results more equitable to the plaintiff in other cases. The Fifth Circuit in Bennett v. Corroon \& Black Corp. ${ }^{130}$ used the reasonable person standard; although granting defendant's motion for summary judgment on other grounds, the court held that obscene cartoons depicting the plaintiff involved in crude and deviant sexual activities posted on the wall of the public men's room of the office building certainly constituted harassment based on sex. ${ }^{131}$

Any reasonable person would have to regard these cartoons as highly offensive to a woman who seeks to deal with her fellow employees and clients with professional dignity and without the barrier of sexual differentiation and abuse. This is a perfect matrix to grow the hostile environment subjecting a woman to the discriminatory intimidation, ridicule, and insult which Title VII protects against. ${ }^{132}$

The language of this decision indicates that the reasonable person standard can be applied in a way that is sensitive to a woman's particular concerns within her working environment that may be very different from those of a man. Proponents of the reasonable woman standard would argue, however, that the level of sensitivity displayed by the Bennett court is highly unusual and that the reasonable person standard generally has a much higher margin for error than does the reasonable woman standard. ${ }^{133}$

130. 845 F.2d 104 (5th Cir. 1988), cert. denied, 489 U.S. 1020 (1989).

131. Id. at $105-06$.

132. Id. at 106 (emphasis added).

133. Of the cases using the reasonable person standard, more have had negative results for the plaintiff than have had positive, and of cases using the reasonable woman standard, more have had positive results for the plaintiff than have had negative-a factor weighing in favor of the reasonable woman test. For reasonable person cases with negative results, see Scott v. Sears, Roebuck \& Co., 798 F.2d 210, 213-15 (7th Cir. 1986); Kirkland v. Brinias, 741 F. Supp. 692, 698 (E.D. Tenn. 1989), aff'd sub nom. LaRue v. Brimas, 944 F.2d 905 (6th Cir. 1991); Ebert v. Lamar Truck Plaza, 715 F. Supp. 1496 (D. Colo. 1987), aff d, 878 F.2d 338 (10th Cir. 1989). For a case with positive analysis using the reasonable woman's perspective, see Bennett v. Corroon \& Black Corp., 845 F.2d 
2. The Reification of Socialized Difference. The creation of a reasonable woman as an entity distinct from the reasonable man is also dangerous in that it may serve to reify and perpetuate those differences that seem to be causing the perception problems we are trying to solve. The reasonable woman standard developed in reaction to apparent differences in the way men and women perceive and are affected by sexual conduct in the workplace. If one acknowledges that these differences are the product of socialization processes, one must also acknowledge that these kinds of differences may be weakened or even eliminated through competing socialization processes that stress mutual humanity as opposed to gendered stereotypes.

Establishing separate legal standards governing the behavior and reasonableness of men and women is tantamount to accepting the inevitability of the suggested differences between men and women. This argument is structured primarily around the power of language. As the language of the reasonable man standard had the effect, at best, of marginalizing women and, at worst, of rendering women legally invisible, so the language of the reasonable woman standard has the power to perpetuate the problems it is designed to resolve. If a judge is asked to consider explicitly the perspective of a female plaintiff as a woman, eventually it will be understood that certain things are reasonable for men and others for women. The societally created difference, reified by way of a legal standard, may be perpetuated because of that standard.

Consider the following examples of ways in which language can mold reality in this context. In his dissent in Ellison $v$. Brady, ${ }^{134}$ Judge Stephens notes that the majority implicitly suggests, by its adoption of a reasonable woman standard, that men do not have the capacity to really understand women. He takes issue with the majority's implication that men "do not have the same sensibilities as women." $135 \mathrm{He}$ argues, reasonably, that men

104, 106 (5th Cir. 1988), cert. denied, 489 U.S. 1020 (1989). For cases with positive results using the reasonable woman standard, see Andrews v. City of Philadelphia, 895 F.2d 1469, 1482-83 (3d Cir. 1990); Smolsky v. Consolidated Rail Corp., 780 F. Supp. 283, 294-95 (E.D. Pa. 1991); Austen v. Hawaii, 759 F. Supp. 612, 628 (D. Haw. 1991), affd, 967 F.2d 583 (9th Cir. 1992); Radtke v. Everett, 471 N.W.2d 660, 664-65 (Mich. App. 1991), appeal granted, 487 N.W.2d 762 (Mich. 1992).

134. 924 F.2d 872 (9th Cir. 1991).

135. Id. at 884 (Stephens, J., dissenting). 
may be expected to understand women's situation with regard to sexual harassment. If true, this argument militates in favor of the reasonable person standard. ${ }^{136}$ Judge Stephens correctly points out that separate standards may have the effect of dividing men and women as opposed to bringing them to an understanding of each other's perspectives.

Consider also the tendency of courts to use the terms "reasonable woman" and "reasonable victim" interchangeably. This use of language encourages the perception of women as victims. Although the Ellison majority uses the terms "reasonable woman" and "reasonable victim" interchangeably, Judge Stephens seems correct in focusing on the "reasonable woman" terinmology. The Ellison majority is concerned with emphasizing the perception gap between men and women; thus the "woman" aspect of the standard is paramount. Other courts that have adopted Ellison's stance also use the "reasonable woman" terminology. ${ }^{137}$ Legal scholars have written about the possibilities of reasonable woman and reasonable victim standards for several years, and have tended, in their articles, to use the terins "woman" and "victim" interchangeably. ${ }^{138}$

136. Ideally, although this assertion may be true, it does not lessen the significance of the majority's argument that gender is a factor which needs to be recognized explicitly because of the current differences between the socialization processes of men and women. In making determinations about offensive and hostile environments, it will be useful for a male judge to keep in mind that the female plaintiff he is considering may have had a markedly different response to the alleged behavior than he, as a male, might have.

It is ironic that, in the same paragraph in which Judge Stephens argues for men's ability to understand women, their circumstances, and concerns, he also argues that the reasonable man standard traditionally means the average adult person. If the standard means "person," it is curious that it does not say "person." Considering women's historical legal categorization with idiots and children, it is doubtful that traditional tort law really expected the court to factor in the reasonableness of all adults.

Judge Stephens's last point in dissent is factually incorrect: He analogizes the focus on the victim of sexual harassment to the focus placed by defense attorneys in rape trials on the victim's conduct, id.; however, the proposed focus in sexual harassment cases is on the victin's perspective, not on her conduct. A more appropriate analogy would be between a victim in a rape trial and a victim in a sexual harassment case governed by the Meritor standard which allows investigation into the victim's manner of speech and dress as a factor in assessinent of "unwelcomeness" of alleged conduct. See supra text accompanying notes 56-63.

137. See Austen v. Hawan̈, 759 F. Supp. 612, 628 (D. Haw. 1991), affd, 967 F.2d 583 (9th Cir. 1992); Radtke v. Everett, 471 N.W.2d 660, 664 (Mich. App. 1991), appeal granted, 487 N.W.2d 762 (Mich. 1992).

138. See, e.g., Holtzman \& Trelz, supra note 23, at 258 ("[T]he woman's 'reasonable' view should control. Unfortunately, adopting the victim's viewpoint is inherently subjective .... . The courts are, however, capable of reconciling the subjectivity of a victim's view with a 'reasonable woman' standard."); Note, Sexual Harassment Claims of Abusive 
"The proper perspective is the objective one of the reasonable victim ... . By adopting the woman's point of view as the norm, the courts might heighten male sensitivity to the effects of sexually offensive conduct in the workplace."139 This tendency to use the two terms interchangeably undoubtedly arises from the fact that because most cases concern harassment of women, a reasonable victim in these cases will be a woman. Considered separately, the reasonable woman and the reasonable victim standards have very different implications-the one focusing on gender, the other on power. The language employed in either version of the revised standards has evolved to address alleged differences in the way men and women perceive sexual conduct. These differences are arguably products of our socialization processes rather than our biological processes. Accepting this assumption, there is potential for societal change. As more and more women enter the workplace, as fewer jobs are overwhelmingly male-dominated, and as society's perceptions of women evolve, it is conceivable that this perception gap may narrow of its own accord. The reasonable woman standard offers a band-aid for the present problem, a short-term solution. With any luck and a great deal of perseverance, a reasonable person standard might actually work in the future if inen and women are able to move beyond the particular stage of gender-role stagnation existing today. Hopefully, the rationale currently supporting a reasonable woinan standard will be incoinprehensible to future generations. The establishment of a separate standard for woinen at this point in time, when women are entering the paid work force in ever-increasing numbers, poses a serious practical risk: The very existence of such a standard may reinforce the very socialized differences we now seek to eradicate and move beyond.

\section{The Practical Arena: The Use of the Reasonable Woman's Per- spective Has Produced Negative Results}

Although the Nimth Circuit illustrated that the reasonable woman standard can be applied effectively, the reasonable woman's perspective has been used in a manner the Ellison majority did not consider explicitly. In Rabidue $v$. Osceola Refining

Work Environment Under Title VII, 97 HARV. L. REV. 1449, 1459 (1984).

139. Note, supra note 138 , at 1459 . 
Co. ${ }^{140}$ the Sixth Circuit applied a reasonable person test. ${ }^{141}$ The Rabidue district court, however, liad relied on the perspective of an "average female employee" to produce the reasoning on which the Sixth Circuit, in turn, relied so heavily. The result obtained by using this "average female employee" perspective is remarkably detrimental to women's interests. The district court's opinion, ${ }^{142}$ from which Judge Krupansky later borrowed much of his stultifying language, offers a vivid example of the way in which a reasonable woman standard can be used to eradicate the very benefits the Ellison court envisioned.

The district court analyzed the facts of Rabidue under the EEOC guidelines, which require harassing conduct to cause unreasonable interference before it is actionable. ${ }^{143}$ The court noted that the word "unreasonably" in section 1604.11(a)(3) gives the court discretion to consider "the nature of the employment environment ... the educational background of the plaintiff's co-workers and supervisors, the physical make up of the plaintiff's work area, and the reasonable expectation of the plaintiff with respect to the kind of conduct that constitutes sexual harassment."144 The court evaluated each aspect of the claim separately and found that the plaintiff did not state a case for interference witl work performance, intimidation, or hostility. As to interference with work performance, "the court concluded that the vulgar language ["cunt," "pussy," "tits," "fat ass"] and sex oriented posters [explicit pornography] did not interfere with plaintiff's work performance. Plaintiff's work problems resulted from her temper and stubbornness." "145 As to intimidation, "[t]he Court believe[d] that plaintiff was not at all fearful while employed at Osceola. The evidence simply does not reflect that plaintiff ever felt fear on the job."146 Regarding hostility, the court opined that "[t]he language and posters were not so drastic as to affect plaintiff's psychological well-being. The evidence reflects that the co-worker's language was annoying, but not so sliocking or severe as to actually affect the

140. 805 F.2d 611 (6th Cir. 1986), cert. denied, 481 U.S. 1041 (1987).

141. See supra Section III(A).

142. Rabidue v. Osceola Ref. Co., 584 F. Supp. 419 (E.D. Mich. 1984), affd, 805 F.2d 611 (6th Cir. 1986), cert. denied, 481 U.S. 1041 (1987).

143. 29 C.F.R. $\$ 1604.11$ (a) (1991); see supra text accompanying notes 3-6.

144. Rabidue, 584 F. Supp. at 430.

145. Id. at 432.

146. Id. 
psyches of female employees. Thus, the hostile environment theory must be rejected."147 The highly subjective nature of these value judgments made by the district court is painfully obvious, regardless of the "evidence" (never explicitly described) that allegedly supported its conclusions.

Acknowledging that the word "offensive" may encompass a greater spectrum of behavior than the word "hostile," the court also stated that the plaintiff had not met even this low threshold. The court proceeded to forge its own "objective" test for an offensive work environment:

[A]n offensive work environment is created where ... the complained of conduct is so significant a factor that the average female employee finds that her overall work experience is substantially and adversely affected by the conduct. Under this standard the sexual harassment need not be psychologically disabling. On the other hand, trivial and merely annoying vulgarity would not constitute sex harassment. ${ }^{148}$

As illustrated by the district court's opimion in Rabidue, the reasonable woman test and the elicitation of the woman's point of view are not mumcible tools. They do not promise a satisfying or necessarily "reasonable" outcome. Regarding "offensiveness," the district court once agam found that the plaintiff had not made out a case: "[P]laintiff's overall work experience was not substantially affected by Mr. Henry's vulgarity. Instead, the vulgarity merely constituted an annoying-but fairly insignificant-part of the total job environment."149 Even considering the pornographic posters along with the excessive vulgarity, the court still did not perceive the "offensiveness" of the environment. The most frightening aspect of this case, a fundamental feature that is mirrored by the Sixth Circuit's ensuing opinion, is the willingness of the court to extrapolate a standard of offensiveness applicable to the work environment from the societal status quo. The convoluted reason-

147. Id.

148. Id. at 433 (emphasis added). Once agam, it is important to notice that the court determined the case by forging its own interpretation of what a reasonable woman (average female employee) would find trivial or merely annoying. This interpretive process cannot be overemphasized; it is during this process that the very different perceptions of men and women may become most obvious.

149. Id. 
ing applied by this court can only be conveyed by its own revealing language.

No evidence was offered indicating that plaintiff has any especial sensitivity to erotic pictures. Furthermore, as the Court has mentioned, the subsection 3 standard pertains to the average female employee. In other words, the test is an objective one.

For better or worse, modern America features open displays of written and pictorial erotica. Shopping centers, candy stores and prime time television regularly display pictures of naked bodies and erotic real or simulated sex acts. Living in this unilieu, the average American should not be legally offended by sexually exphicit posters.

The Court finds that the posters had a de minimis effect on plaintiff's work environment .... [T] he Court concludes that Mr. Henry's vulgar language combined with the sexually explicit posters was not enough to make plaintiff's working environment offensive under 29 CFR sec. 1604.11(a)(3). ${ }^{150}$

Although the district court acknowledges the relevance of the view of the "average female employee" in the first quoted paragrapl, it replaces this language witl the term "tlie average Ainerican" in the second quoted paragraph; consequently, the distinction between these two theoretically discrete entities is elided. The district court's attempt to use an objective female viewpoint, and the Sixtl Circuit's subsequent affirmance of the disastrous result, militate agaimst the adoption of a reasonable woman standard. The susceptibility of the reasonable woman to views that are more culturally masculine demands a careful evaluation of this proposed legal reform. The district court's opinion validates the following observation: "Even a reasonable woman standard, when it is not carefully elaborated by a discussion of the differences between inen and women, may reflect less an effort to see beyond the male perspective, than an attempt to evoke a woman wlio is, in Henry Higgins's words, 'more like a man.' "151 The district court's use of

150. Id. Note the paradoxical situation in which the court placed the plaintiff. The court stated that no evidence was offered indicating a special sensitivity to pornography. This standard is supposed to be an objective one. The average person, according to the second quoted paragraph, should not be offended by pornography. Notice that, even if Vivienne Rabidue could have presented evidence supporting the fact that she was personally offended, she could not recover because she then would have been the rare hypersensitive employee. By uncritically using societal norms as a standard of evaluation, the court placed Rabidue in a no-win situation.

151. Abrams, supra note 31, at 1201. 
the reasonable woman standard produced the exact same results as the Sixth Circuit's use of the reasonable person standard in Rabidue. This misdirected use of the reasonable woman standard suggests that the problem is not in the standard's terminology, but in the perspective of the persons applying the standard. In any case, the Rabidue district court decision demonstrates that the reasonable woman standard is susceptible to debilitating application in much the same way that the reasonable person standard is susceptible.

The argument can be made that all standards employing a reasonableness analysis will be susceptible to this type of debilitating application in that particular applications will undoubtedly reflect the bias of the persons charged with applying the standards. ${ }^{152}$ Although there is truth to this criticism, it does not diminish the significance of the argument that there are several problems with the reasonable woman standard, as illustrated in this Part. It is the particular combination of problems inherent in the reasonable woman standard that makes the proposed standard an ineffective, potentially harmful reform. Imagine an inverted triangle and place the reasonable person standard along the flat surface at the top of the figure. As one progresses downward to the point of the triangle, the reasonable woman standard may be placed in the middle of the figure and the reasonable victim standard at the bottom. This figure visually represents the discretion a judge has to impose his personal perceptions and biases while applymg each of these standards. A decisionmaker's discretion decreases as the focus on the individual plaintiff's perception is sharpened. The "gender-neutral" reasonable person terminology involves the greatest margin for error because neutral language makes it easier to ignore the illuminating perception difference that the reasonable woman standard highlights. ${ }^{153}$ The reasonable

152. The reasonable victim standard offered as an alternative solution in Part $\mathrm{V}$ poses this problem, though it does so to a lesser degree.

153. For a comparison of positive and negative results produced by the application of both the reasonable person and reasonable woman standards, see supra note 133. The Rabidue district court decision is the only case available purporting to use a reasonable woman standard that ends so disastrously for the plamtiff. EEOC v. Blue Diamond Growers Assoc., No. 90-2281, 1992 U.S. Dist. LEXIS 910 (D.N.J. Jan. 28, 1992), affd without op., 980 F.2d 727 (3d Cir. 1992) (plaintiff loses motion for summary judgment after application of reasonable woman standard); see also Djallah v. East Bay Mun. Util. Dist., No. C-90-2853-JPV, 1991 U.S. Dist. LEXIS 15913 (N.D. Cal. Oct. 18, 1991) (using reasonable woman standard finding that events described by plaintiff do not support 
victim terminology presents a similar problem of susceptibility to bias, but it is narrower in scope. Further, because this standard employs the victim terminology, it entails neither the practical consequences of the theoretical problems of marginalization and reification of difference nor the defimitional quandary posed by the reasonable woman standard.

\section{THE Best Alternative: THE REASONABLE VICTIM STANDARD}

Adopting a reasonable victim standard with an explicit gender analysis as a relevant and necessary element of the case evaluation would solve many of the concerns of both the reasonable person and the reasonable woman proponents. Although scholars who have suggested the reasonable victim standard have often argued alternatively that the woman's view should control, thereby conflating the two standards, ${ }^{154}$ the reasons they offer in support of the reasonable victim standard are sound. The offensiveness of the conduct should be evaluated from the viewpoint of the "reasonable victim." The reasonable victim standard, while objective in its imsistence on reasonableness, is slightly subjectified by the victim aspect of the standard, which draws the attention of judges to the power differential implicit in the relationship of the parties involved. The power dynamics analyzed in this relationship can mclude the male/female relationship as well as the employer/employee relationship. ${ }^{155}$ The objective aspect of the standard embodied by the "reasonableness" language will protect defendants from hypersensitive plaintiffs. Of course, this framing of the standard does not elimmate the problems encountered when courts too quickly characterize complainants as hypersensitive, but the added prong requiring evaluation of gender implications will help allevi-

\footnotetext{
finding of sexually hostile work environment).

154. See, e.g., Holtzman \& Trelz, supra note 23 , at 257-58; Note, supra note 138, at 1459.

155. This standard can also encoinpass the less common cases, such as the male employee harassed by a female supervisor, or a fenale employee harassed by a male employee who, though not her subordinate, occupies a lower position on the corporate ladder. It would also apply to cases of same-sex harassment. The power differential in these situations is concededly less than and substantially different from the prototypical case in which the male supervisor harasses a female employee whom he has the ability to hire, fire, and promote at will. But the reasonable victim standard can accommodate all of these situations.
} 
ate this situation. Attention to the gender of the victim can protect female victims from behavior that men may not view as offensive, by allowing for recognition as offensive or hostile behavior that the average American male, i.e., the reasonable person, may not view as such.

"Adoption of the reasonable victim standard of assessing offensiveness should help remove sexual stereotypes from the legal system." 156 Removing the focus from sexual stereotypes is an important benefit of the "reasonable victim" terminology. The reasonable woman standard has the tendency to encourage generalizations about women as a group that may be detrimental to an individual woman's case. The dynamics of group oppression should be integral to any sexual harassment analysis under Title VII but should not obscure the analysis as to the harm inflicted on the individual plaintiff as a specific victim. Emphasizing power, the terminology of the reasonable victim standard does not focus on gender as the primary criterion of evaluation. This simple change will retard the ease of generalization about what women as a group thimk and feel, allowing courts to address the situation of the individual woman in the context of her particular working environment. However, the explicit gender analysis prescribed by this standard will prevent courts from ignoring or overlooking those differences in perception apparent between men and women at this time in our society.

Furthermore, the use of the term "gender" as opposed to "woman" in the language of the suggested standard encourages a recognition that the apparent differences between men and women are the products of socialization rather than biology, and consequently susceptible to change. A focus on gender in addition to sex will help move us away from the essentializing aspects of the reasonable woman standard. Gender is not always aligned with sex. For example, a woman can have masculine gendered characteristics and a man may have feminine gendered characteristics; both may be discriminated or harassed for these very reasons. Acknowledgement of this reality will also move judges away from the tendency to essentialize women. Although the label "woman" is readily and accurately assigned to a biological female, the gender "feminine" is not as easy to assign. The entire focus of the

156. Holzman \& Trelz, supra note 23, at 258. 
case will be on circumstances affecting the particular individual: the power dynainic giving rise to the harassment situation; the victim's sex; and the gendered characteristics of the plaintiff that may have added to the offensiveness or hostility experienced by that plamtiff.

Although any objective consensus on what is or is not appropriate sexual conduct in the workplace is impossible in light of the vastly differing perceptions of men and women today, these differences are a product of socialization processes that can be modified over time. As more women enter the work force at all levels, and the power differential between men and women as societal groups is mimimized, a more rational and mutual understanding of appropriate conduct in the workplace will evolve. A reasonable victim standard could readily adapt to this evolution, whereas a reasonable woman standard, by explicitly suggesting that women are somehow fundamentally, unchangeably different from inen, inilitates through its language against the very evolution we hope will take place. This argument is largely semantic, but the language used to frame the analysis can have a great impact on the substantive evaluation of sexual harassment cases.

The thoughtful analysis undertaken by the Ninth Circuit in Ellison v. Brady $y^{157}$ would not change very much under the proposed standard. The only difference would be the definitive adoption of a reasonable victim standard requiring an explicit evaluation of gender. The language chosen to implement substantive changes in sexual harassment law may have long-term effects not yet contemplated by the progressive and openminded Ninth Circuit. These consequences warrant the thoughtful consideration of the proposed version of the reasonable victim standard.

157. 924 F.2d 872 (9th Cir. 1991). 